NBER WORKING PAPER SERIES

\title{
INTEGRATING INDUSTRY AND NATIONAL ECONOMIC ACCOUNTS: FIRST STEPS AND FUTURE IMPROVEMENTS
}

\author{
Ann M. Lawson \\ Brian C. Moyer \\ Sumiye Okubo \\ Mark A. Planting \\ Working Paper 11187 \\ http://www.nber.org/papers/w11187 \\ NATIONAL BUREAU OF ECONOMIC RESEARCH \\ 1050 Massachusetts Avenue \\ Cambridge, MA 02138 \\ March 2005
}

The authors wish to acknowledge Matthew Atkinson, Mahnaz Fahim-Nader, Jiemin Guo, Karen Horowitz, Sherlene K. S. Lum, George Smith, and all other staff of the Industry Accounts Directorate at BEA, who made significant contributions directly and indirectly to the development of this paper. We thank Jack Triplett, Eric Bartelsman, and other participants of the NBER/CRIW conference in April 2004 for their many helpful comments on the direction of this research. The views expressed herein are those of the author(s) and do not necessarily reflect the views of the National Bureau of Economic Research.

(C) 2005 by Ann M. Lawson, Brian C. Moyer, Sumiye Okubo, and Mark A. Planting. All rights reserved. Short sections of text, not to exceed two paragraphs, may be quoted without explicit permission provided that full credit, including (C) notice, is given to the source. 
Integrating Industry and National Economic Accounts: First Steps and Future Improvements Ann M. Lawson, Brian C. Moyer, Sumiye Okubo, and Mark A. Planting

NBER Working Paper No. 11187

March 2005

JEL No. C13, C67, C81, E01, L16

\begin{abstract}
The integration of the annual I-O accounts with the GDP-by-industry accounts is the most recent in a series of improvements to the industry accounts provided by the BEA in recent years. BEA prepares two sets of national industry accounts: The I-O accounts, which consist of the benchmark I-O accounts and the annual I-O accounts, and the GDPby- industry accounts. Both the I-O accounts and the GDP-by-industry accounts present measures of gross output, intermediate inputs, and value added by industry. However, in the past, they were inconsistent because of the use of different methodologies, classification frameworks, and source data.
\end{abstract}

The integration of these accounts eliminated these inconsistencies and improved the accuracy of both sets of accounts. The integration of the annual industry accounts represents a major advance in the timeliness, accuracy, and consistency of these accounts, and is a result of significant improvements in BEA's estimating methods. The paper describes the new methodology, and the future steps required to integrate the industry accounts with the NIPAs. The new methodology combines source data between the two industry accounts to improve accuracy; it prepares the newly integrated accounts within an I-O framework that balances and reconciles industry production with commodity usage. Moreover, the new methodology allows the acceleration of the release of the annual I-O accounts by 2 years and for the first time, provides a consistent time series of annual I-O accounts.

Three appendices are provided: A description of the probability-based method to rank source data by quality; a description of the new balancing produced for producing the annual I-O accounts; and a description of the computation method used to estimate chaintype price and quantity indexes in the GDP-by-industry accounts.

Ann M. Lawson

Bureau of Economic Analysis

Brian C. Moyer

Sumiye Okubo

Mark A. Planting 


\section{Table of Contents}

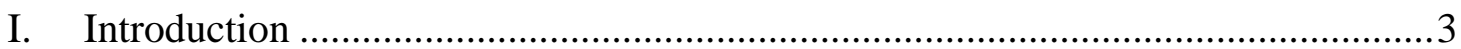

II. Partial Integration: The First Step ......................................................... 7

1. The Traditional I-O Accounts Methodology ..........................................8

2. The Traditional GDP-by-Industry Accounts Methodology ..........................9

3. Combining the Two Methodologies .......................................................11

III. Full Integration: The Long-run Goal ........................................................... 15

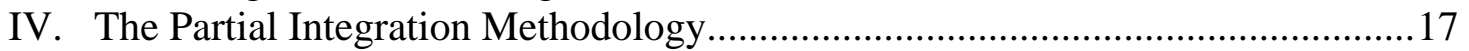

1. Step 1: Level of Industry and Commodity Detail.....................................18

2. Step 2: Revised 1997 Benchmark I-O Accounts ....................................18

3. Step 3: A Time Series of Value Added for 1998-2002..............................23

4. Step 4: Updated and Balanced Annual I-O Accounts for 1998-2002........24

a. Industry and Commodity Gross Output .....................................24

b. Intermediate Inputs to Industries ............................................25

c. Domestic Supply ...................................................................26

d. Commodity Composition of Final Uses excluding Imports and Exports and Changes in Private Inventories .................................26

e. Balancing the Use Table .........................................................27

5. Step 5: Price and Quantity Indexes for the GDP-by-Industry Accounts ...27

a. Indexes for Gross Output and Intermediate Inputs by Industry .....28

b. Indexes for Value Added by Industry .......................................28

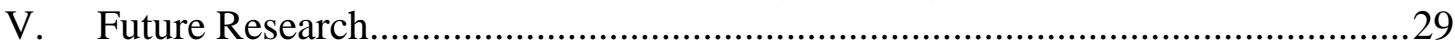

Appendix A. Estimating the "Combined” Level of Value Added by Industry ............31

Appendix B. New Updating and Balancing Processes for BEA's Annual

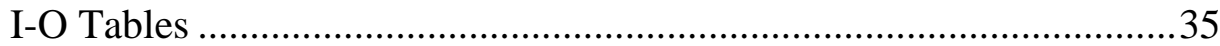

Appendix C. Computing Chain-Type Price and Quantity Indexes in the GDP-by-Industry Accounts ..........................................................44

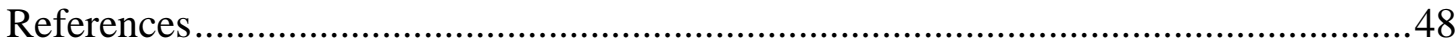

Table A1: Comparison of BLS and Census Nonagricultural Payroll Data for Selected Private Industries, 1992 .........................................................50

Table A2: BLS and Census Nonagricultural Payroll Data for Private Industries: Comparison of Levels, 1992 and 1997 ...................................................51

Table A3: Comparisons in Growth Rates for Census and BLS Payroll Data

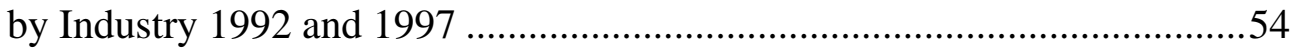

Table B: Industries and Commodities in the Integrated Accounts ............................56

Table C: NIPA Changes Incorporated into the 1997 Benchmark I-O Accounts ........57

Table D: 1997 Industry Value Added Estimates .....................................................58

Table E: Principal Source Data for Value-Added Extrapolators .................................60

Table F: Principal Sources of Data for Industry and Commodity Output and Prices..61

Chart 1: Use Table: Commodities Used by Industries and Final Uses......................69

Chart 2: Components of GDI-Based Value Added by Industry .................................70

Chart 3: Relationships Among National Economic Accounts....................................71

Chart 4: Merging Information for Setting Value-Added Levels .................................72

Chart 5: Probability Distributions of Value Added for Educational Services ..............73 


\section{Integrating Industry and National Economic Accounts: First Steps and Future Improvements}

Ann M. Lawson, Brian C. Moyer, Sumiye Okubo, and Mark A. Planting

\section{Introduction}

As part of its continuing efforts to improve the system of economic accounts, the Bureau of Economic Analysis (BEA) has begun a series of strategic initiatives to ultimately integrate the gross-domestic-product-(GDP)-by-industry, annual input-output (I-O), and benchmark I-O programs within the industry accounts, as well as to integrate the industry accounts with the national income and product accounts (NIPAs). ${ }^{2}$ Full achievement of this goal will require several years of effort by BEA, as well as the continuing participation and cooperation by other statistical agencies, particularly the Bureau of the Census and the Bureau of Labor Statistics (BLS), to further enhance source data. In the interim, BEA has moved forward with integrating two out of three of its industry programs — specifically the merging of the GDP-by-industry accounts with the annual I-O accounts. Initial results of this effort will be released in June 2004 as part of BEA's 5-year comprehensive revision.

The integration of the GDP-by-industry accounts with the annual I-O accounts is the most recent in a series of improvements to the industry accounts. These improvements include the following: Resuming the publication of the annual I-O accounts; accelerating the release of the annual I-O accounts to within 3 years after the

\footnotetext{
${ }^{2}$ In addition, it is BEA's long-run goal to integrate the industry accounts and NIPAs with related regional accounts, namely gross state product (GSP) by industry and regional I-O multiplier estimates. Consistency between the annual I-O accounts and the GDP-by-industry accounts will improve the quality of the GSP accounts, and any increase in timeliness of the GDP-by-industry estimates will be reflected in more speedy delivery of the GSP estimates. Consistent and better measures of value added would also potentially strengthen the links between the GSP accounts and the regional I-O multiplier estimates.
} 
end of the reference year; expanding the GDP-by-industry accounts to include gross output and intermediate inputs for all industries; developing an accelerated set of GDPby-industry accounts that are available with a lag of 4 months after the end of the reference year; and continuing to work closely with the Bureau of the Census on new initiatives to improve the quality and the timeliness of the source data used to prepare the industry accounts.

With these improvements to the industry accounts in place, as well as with the general improvements made to the quality of industry source data, BEA is ready to integrate the annual I-O accounts and the GDP-by-industry accounts as a first step towards full integration. ${ }^{3}$ For purposes of the current paper, this integration is being referred to as "partial integration" and is the first tangible result of the initiative to reach BEA's data users.

This partial integration could have been achieved through a variety of methods. For example, many countries produce integrated annual I-O accounts and GDP-byindustry accounts by assuming that the industry ratios of intermediate inputs to gross output do not change from the most recent set of benchmark I-O accounts. By making this assumption, these ratios are then used to estimate a time series of value added by industry from the annual source data on gross output by industry. BEA has taken a very different approach in developing its integration methodology because of the richness of the source data that are available in the United States. For example, the Bureau of the Census, BLS, and the Internal Revenue Service (IRS) provide data that can be used to estimate value added by industry in various ways. However, the quality of these source

\footnotetext{
${ }^{3}$ For a discussion on integrating the industry accounts, see Yuskavage (2000).
} 
data varies by data series and by industry, particularly in terms of their relative coverage and definitional consistency. As a result, BEA has developed a method that ranks the available source data based on measures of coverage and consistency, among other factors, and then estimates a balanced set of annual I-O accounts and GDP-by- industry accounts that incorporate the resulting weighted average of these source data. In this manner, BEA’s integrated annual I-O accounts and GDP-by-industry accounts will provide a more consistent and a more accurate set of estimates.

For full integration of the industry accounts, the measure and level of value added by industry for the industry accounts will be based on the benchmark I-O accounts, beginning with the 2002 accounts. These accounts are prepared for years of the quinquennial economic census and are currently used to establish the measure and level of final expenditures by use category contributing to GDP in the NIPAs. Annual updates of the integrated industry accounts would be based on less comprehensive survey and administrative record data available in nonbenchmark years. For full integration, the measures of value added by industry would be independent of the NIPA measures of gross domestic income (GDI), and would provide a "feedback" loop to the NIPAs that would improve the estimates of the commodity composition of GDP final expenditures. ${ }^{4}$ To achieve this ambitious goal, BEA is working cooperatively with the Census Bureau, BLS, and other statistical agencies to make the necessary improvements to the quality

\footnotetext{
${ }^{4}$ BEA currently uses two approaches to measure GDP: The expenditures approach and the income approach. The expenditures approach measures GDP as the sum of consumption spending, investment spending, government expenditures, and exports minus imports. The income approach measures GDP as the sum of compensation of employees, taxes on production and imports, less subsidies, and gross operating surplus. These approaches allow maximum use of up-to-date, high-quality economic indicators from the Bureau of the Census, the IRS, and the BLS to produce timely, reliable measures of the economy's current performance.
} 
and coverage of the underlying source data, particularly for information on industry expenses.

This paper has five sections and three appendices. The first section is this introduction. The second section describes in greater detail the partial integration being achieved in the short run. The third section presents BEA's vision for full integration in the long run, including some of the major requirements for achieving this goal as well as the major benefits. The fourth section describes the methodology developed for the partial integration of the annual industry accounts. The last section outlines the future steps required to reach the goal of full integration. The appendices include an expanded description of the probability-based method used to develop a weighted-average estimate of each industry’s gross operating surplus; a detailed description of the new balancing procedure developed for automating production of the annual I-O tables; and a statement of the computation method used to estimate chain-type price and quantity indexes in the GDP-by-industry accounts.

Highlights of the partial integration methodology are as follows:

- It allows BEA to incorporate the most timely and highest quality source data available into both the annual I-O accounts and the GDP-by-industry accounts.

- The annual I-O accounts and the GDP-by-industry accounts will be released concurrently for 1998-2002 in June of this year, and for the first time both sets of accounts will present fully consistent measures of gross output, intermediate inputs, and value added by industry.

- The quality of the annual industry accounts will be improved because the accounts will be prepared within a balanced I-O framework; that is, all the 
components of the accounts will be in agreement within a balanced row-andcolumn framework.

- The release of the annual I-O accounts will be accelerated by 2 years in a sequence of two steps that will be completed by the fall of 2004, when they will be released 1 year after the end of the reference year.

- For the first time, the 1998-2002 annual I-O accounts will be presented as a consistent time series; as a consequence, the annual I-O accounts will be more useful for analyses of trends over time.

\section{Partial Integration: The First Step}

BEA prepares two sets of national industry accounts: The I-O accounts, which consist of the benchmark I-O accounts and the annual I-O accounts, and the GDP-byindustry accounts. Both the I-O accounts and the GDP-by-industry accounts present measures of gross output, intermediate inputs, and value added by industry; however, they are often inconsistent because of the use of different methodologies, classification frameworks, and source data. These inconsistencies are frustrating to data users, who would like to be able to combine the richness of information from each for their own applications. The goal of partial integration is to eliminate these inconsistencies, as well as to improve the accuracy of the combined accounts by drawing on their relative strengths in methodologies and source data. In this section, the traditional I-O and GDPby-industry methodologies are reviewed and the comparative advantages of each are examined in the context of an integrated methodology that produces both sets of accounts. 


\section{II.1 The Traditional I-O Accounts Methodology}

The I-O accounts present a detailed picture of how industries interact to provide inputs to, and use output from, each other to produce the Nation's GDP. The I-O accounts consist of benchmark I-O accounts and annual I-O accounts. The benchmark IO accounts are prepared every 5 years and are based on data from the quinquennial economic census covering most businesses. ${ }^{5}$ The annual I-O accounts update the most recent benchmark I-O accounts, and, although they are more timely than the benchmark I-O accounts, they are generally less detailed because they rely on annual data based on smaller sample surveys. ${ }^{6}$ At present, the I-O accounts are prepared only in current dollars. ${ }^{7}$

Both the benchmark and the annual I-O accounts are prepared within a balanced row-and-column framework that is presented in two tables: A "make" table and a "use" table. The make table shows the commodities that are produced by each industry, and the use table shows the commodities that are used in industry production and that are consumed by final users. In the use table, the columns consist of industries and final uses (chart 1). The column total for an industry is its gross output (consisting of sales or receipts, other operating income, commodity taxes, and inventory change). The rows in the use table consist of commodities and value added. The commodities are the goods and services that are produced by industries or imported and that are consumed either by industries in their production processes or by final users. The commodities consumed by industries in the production process are referred to as intermediate inputs (consisting of energy, materials, and purchased services). Value added in the I-O accounts is computed

\footnotetext{
${ }^{5}$ For more information, see Lawson, et. al. (2002)

${ }^{6}$ For more information, see Planting and Kuhbach.

${ }^{7} \mathrm{BEA}$ is beginning research to explore the feasibility of preparing real (inflation-adjusted) I-O accounts.
} 
as a residual--that is, as gross output less intermediate inputs by industry. In concept, this residual, which represents the sum of the costs incurred and the incomes earned in production, consists of compensation of employees, gross operating surplus, and taxes on production and imports, less subsidies. ${ }^{8}$ GDP equals valued added summed over all industries, and it also equals final uses summed over all commodities.

The I-O accounts have traditionally served two major purposes, both of which have focused on information about the use of commodities and which have supported BEA's NIPAs. First, the accounts have provided the NIPAs with best-level estimates of the commodities that comprise final expenditures for GDP in benchmark years. Second, they provide the NIPAs with information to split estimates of commodities produced annually into their business (intermediate) and final consumer components--information that is critical for estimating GDP final expenditures in nonbenchmark years. Because of their importance in determining the levels of GDP in the NIPAs, the I-O accounts have traditionally focused more on the commodity composition of the economy and less on the measures of value added by industry.

\section{II.2 The Traditional GDP-by-Industry Accounts Methodology}

In contrast to the I-O accounts, the GDP-by-industry accounts have traditionally

focused on the industry composition of the U.S. economy and the relative performance of these industries as reflected in their measures of value added. The GDP-by-industry

\footnotetext{
${ }^{8}$ Previously, these costs and incomes were classified as either compensation of employees, property-type income, or indirect business tax and nontax liability. These new classifications are consistent with the aggregations introduced as part of the comprehensive NIPA revision; see Moulton and Seskin for more information. Specifically, all the nontax liabilities except special assessments are removed from indirect business tax and nontax liability, and the remainder of this category is renamed "taxes on production and imports;” the nontax liabilities except special assessments are added to property-type income; subsidies are removed from property-type income, and the remainder of this category is renamed "gross operating surplus;” and subsidies are netted against the value of taxes on production and imports.
} 
accounts are particularly suited for time series analysis of changes in industry shares of GDP and contributions to GDP growth. They provide annual estimates of gross output, of intermediate inputs, and of value added by industry and the corresponding price and quantity indexes. ${ }^{9}$

The GDP-by-industry accounts use a different estimating approach than that used for the I-O accounts. They measure value added by industry as the sum of the costs incurred and the incomes earned in production. Value added by industry is estimated as the sum of the industry distributions of compensation of employees, gross operating surplus, and taxes on production and imports, less subsidies (chart 2). In the GDP-byindustry accounts, total intermediate inputs by industry are measured as a residual--that is, total intermediate inputs equal gross output less value added for an industry.

The GDP-by-industry estimates are based on data from three primary sources. Gross output by industry is based on establishment-based annual survey data from the Bureau of the Census that are used to extrapolate best-level estimates from the most recent set of benchmark I-O accounts. The measures of value added by industry are derived from the industry distributions of the components of gross domestic income (GDI) from the NIPAs, which, in turn, are based on establishment-based data from the Bureau of Labor Statistics and on enterprise-based annual tax return and administrative record data from the IRS.

Real measures of gross output and intermediate inputs by industry are estimated by deflating with detailed price indexes. Price indexes and quantity indexes are derived for each industry's gross output, of intermediate inputs, and of value added.

\footnotetext{
${ }^{9}$ For more information, see Lum, et. al.
} 


\section{II.3 Combining the Two Methodologies}

The primary strength of the I-O methodology is the balanced row-and-column framework in which the detailed estimates of gross output and intermediate inputs by industry are prepared; this framework allows for a simultaneous look at both the economy's industries and commodities. The primary strength of the GDP-by-industry accounts methodology is the direct approach to estimating a time series of value added by industry from high quality source income data. The methodology for partial integration incorporates the relative strengths of both. It yields a new and improved set of annual IO accounts and GDP-by-industry accounts that are prepared within a balanced framework and that incorporate the most timely and highest quality source data available. It also ensures the consistency of the estimates of gross output, of intermediate inputs, and of value added by industry across the two sets of accounts.

The strength of using a balanced I-O framework is demonstrated by again referring to chart 1 . A balanced use table ensures that the industry estimates of the I-O accounts (the column totals) are in balance with the commodity estimates of the I-O accounts (the row totals). ${ }^{10}$ This framework tracks all of the detailed input and output flows in the economy and guarantees that each commodity that is produced is either consumed by industries as an intermediate input or is consumed by final users. An imbalance in the use table--for example, too little, or too much, supply of a commodity after intermediate inputs by industry and final uses have been accounted for-flags an inconsistency in the data. Therefore, a balanced framework provides a "consistency

\footnotetext{
${ }^{10}$ The I-O framework also includes a balanced make table, which requires that the different commodities produced by industries are consistent with total commodity and industry outputs for the economy.
} 
check" of the use table. No comparable procedure to balance industries and commodities exists for the GDP-by-industry accounts.

The strength of the GDP-by-industry methodology is that the estimates of value added by industry are derived directly from high quality source data, so these measures generally provide better estimates of value added for industries relative to the I-O estimates. Nonetheless, several factors can affect the quality of the GDP-by-industry estimates for specific industries. For example, gross operating surplus, one component of value added by industry, includes several items--such as corporate profits before tax, corporate net interest, and corporate capital consumption allowances--that are based on corporate tax return data from the IRS. Because the consolidated tax return data of an enterprise may account for activities by several establishments classified in different industries, BEA must convert these enterprise- or company-based data to an establishment or plant basis. The conversion can introduce errors because it is based on employment data for establishments that are cross-classified by enterprise, and because it is based on relationships from an economic census year that are likely to change over time. In addition, proprietors' income, another component of gross operating surplus, can introduce errors because the industry distributions of proprietors' income are based on incomplete source data. Industries with large shares of value added from proprietors' income are regarded as having lower quality estimates. ${ }^{11}$

\footnotetext{
${ }^{11}$ Proprietors' income is defined here to equal the sum of NIPA estimates for proprietors' income without inventory valuation adjustment (IVA) and capital consumption adjustment (CCAdj), proprietors' net interest, proprietors' capital consumption allowance, and proprietors' IVA. The NIPA adjustment to nonfarm proprietors' income without IVA and CCAdj for misreporting on income tax returns is shown in NIPA table 7.14 "Relation of Nonfarm Proprietors' Income in the National Income and Product Accounts to Corresponding Measures as Published by the Internal Revenue Service.”
} 
The GDP-by-industry measures of value-added may be of a higher or lower quality than those from the benchmark I-O accounts, depending on the data used. For an industry with high quality data on gross output and intermediate inputs, the measure of value added from the benchmark I-O accounts may be superior, particularly when the GDP-by-industry measure includes a large enterprise-establishment adjustment or a substantial amount of proprietors' income. Alternatively, for an industry with a small enterprise-establishment adjustment and a negligible amount of proprietors' income, the GDP-by-industry measure may be superior, particularly if the coverage of intermediate inputs in the quinquennial economic census is small for the benchmark I-O measure. For the 1997 benchmark I-O accounts, less than half of all intermediate inputs were covered by the economic census; for many industries, this results in lower quality measures of value added. In contrast, for nonbenchmark years, the GDP-by-industry accounts always provide the preferred measures of value added, because estimates of intermediate inputs in the annual I-O accounts are currently based on very sparse data and are unable to yield high quality measures of value added by industry. ${ }^{12}$

The advantages of a partial integration methodology, however, go beyond incorporating the best methods and source data from each methodology. Because the annual I-O accounts will be estimated concurrently with the GDP-by-industry accounts, they will be released on an accelerated schedule. The 2002 annual I-O table, scheduled for release in June 2004, will be released 18 months rather than 36 months after the end of the reference year. In addition, beginning in the fall of 2004, the annual I-O accounts

\footnotetext{
${ }^{12}$ The Bureau of the Census has recently undertaken initiatives to improve the coverage of intermediate inputs by industry in several of its annual surveys. For example, the Annual Survey of Manufactures has expanded its coverage of expenses to include purchased services by industry and the Service Annual Survey has initiated the collection of data on expenses by industry.
} 
will adopt the revision schedule of the NIPAs; at that time, the revised tables for 2001 and 2002 and new tables for 2003 will be released. The revised I-O estimates that are consistent with the annually revised NIPA estimates will provide users with yet another level of consistency. Finally, the partial integration methodology will impose a time series consistency on the annual I-O tables, making the tables more useful for analyses of trends over time.

A further advantage of the partial integration methodology is a "feedback loop" to the NIPAs that is demonstrated by examining the relationships among the national accounts (chart 3). Before the integration of the annual I-O accounts and the GDP-byindustry accounts, the benchmark I-O accounts provided the following: A starting point for updating the annual I-O accounts (arrow 1), the best-level estimates of gross output to the GDP-by-industry accounts (arrow 2), and the best-level estimates and commodity splits of GDP to the NIPAs (arrow 3). The NIPAs provided estimates of GDI by industry to the GDP-by-industry accounts (arrow 4) and information on the annual composition of GDP to the annual I-O accounts (arrow 5). The partial integration results in an exchange of information between the annual I-O accounts and the GDP-by-industry accounts (arrow 6), and it also provides a feedback loop to the NIPAs (arrow 7). Because the integrated industry accounts will be prepared within a balanced framework, they will provide annual estimates of the commodity composition of GDP final expenditures that could potentially be used to improve the NIPA measures of GDP. 


\section{Full Integration: The Long-Run Goal}

Integration of the annual I-O accounts and the GDP-by-industry accounts is only the first step, although a very important one, towards BEA's long-run goal to fully integrate all components of its industry accounts, including the benchmark I-O accounts, and to integrate the industry accounts with the NIPAs. Although full integration is dependent upon continued costly investments by the Federal statistical agencies to improve the coverage and consistency of their economic data, the benefits are significant in providing higher quality information to data users. With more consistent and comprehensive data on industry inputs, the benchmark I-O accounts would provide the best measures of value added by industry for benchmark years. With updated annual information on intermediate inputs by industry, the annual I-O accounts and the GDP-byindustry accounts would provide annual updates of value added by industry that would be independent of the NIPA measures of GDP. With full integration, BEA would have a production-based measure of GDP that would provide new information to the NIPAs through the feedback loop discussed earlier (chart 3). That is to say, it could provide valuable insights into imbalances between BEA's primary measure of GDP based on the final expenditures approach and its "shadow" measure based on income- that is, GDI.

BEA views the underlying framework now being implemented for partial integration as able to accommodate the requirements for full integration. That being said, however, for full integration, the data needed to populate much of this framework is presently missing, particularly consistent and comprehensive data on intermediate inputs for industries. For example, less than half of the intermediate input estimates in the 1997 benchmark I-O accounts were based on high quality, consistent data collected by the 
Bureau of the Census; estimates for the balance were based on fragmented information from trade associations, company annual reports, anecdotal information, and prior benchmark I-O accounts. To be reliable, a production-based estimate of GDP requires an expansion by Census in its coverage of business expenses from less than half to 100 percent. The methods developed by BEA to achieve partial integration in the short run are not an adequate substitute for these improvements to source data in the long run, if the goals of full integration are to be realized. To acquire this information, BEA is working collaboratively with other statistical agencies, particularly the Bureau of the Census to both expand information collected for its annual surveys and for its quinquennial economic census, beginning with that for 2002.

Full integration also implies greater consistency in the data provided by different statistical agencies. For example, the quality of BEA's industry estimates can be affected by inconsistencies in the sampling frames used by the statistical agencies, as well as differences in classification and data collection and tabulation practices. Table A compares estimates of nonagricultural payroll data collected by the Bureau of the Census with wage and salary data collected by BLS for selected industries in 1992. Industries for which comparable information was not available are excluded from the table. The comparison shows that the estimates differ by 10 percent or more for about half of these industries. Although these differences do not directly affect measures of total value added, they can potentially impact the reliability of BEA's estimates of the labor-capital splits of industry value added. BEA envisions that it will be able to further enhance the consistency and quality of its fully integrated accounts because data-sharing initiatives should reveal the sources of these and other similar differences in source data from the 
various Federal statistical agencies. In the case cited, the consistency between its measures of gross output by industry and compensation of employees by industry, would be improved if payroll by industry data prepared by the Bureau of the Census and the wages and salaries data prepared by BLS were brought into agreement by the source agencies.

At the earliest, full integration could not be attained until the 2008-2010 timeframe, which is when expanded data from the 2002 Economic Census will be fully incorporated into BEA's economic accounts, beginning with the release of the 2002 benchmark I-O accounts in 2007. If limited data sharing by statistical agencies is also made viable in the interim, BEA will be able to better identify the sources of the differences in data from other agencies such as those identified in the example presented above for BLS and Census data. The major benefit of such data sharing would be to enhance the consistency and quality of BEA’s fully-integrated economic accounts.

\section{The Partial Integration Methodology}

The methodology, including the source data and the estimating procedures that will be used for the partial integration of the annual I-O accounts and the GDP-byindustry accounts is discussed in this section. The methodology is described in a sequence of five steps: (1) Establishing a level of detail for both industries and commodities; (2) revising the previously published 1997 benchmark I-O accounts that will serve as a reference point for the integrated accounts; (3) developing a 1998-2002 time series for the annual estimates of value added by industry; (4) updating and balancing the annual I-O accounts for 1998-2002, incorporating the revised 1997 
benchmark I-O accounts from step 2 and the 1998-2002 estimates of value added by industry from step 3; and (5) preparing price and quantity indexes for the GDP-byindustry accounts for 1998-2002.

\section{IV.1 Step 1: Level of Industry and Commodity Detail}

The first step in integrating the annual I-O accounts and the GDP-by-industry accounts is to establish the level of detail that can be used for both sets of accounts. Table B shows this detail and the corresponding 1997 North American Industry Classification System (NAICS) industry codes. Table B no longer shows a statistical discrepancy that has traditionally appeared as an industry in the GDP-by-industry accounts. This reflects the use of a balanced framework which requires consistency between GDP measured in terms of final expenditures and in terms of value added or income. In addition, table B does not include an industry for the inventory valuation adjustment, which has traditionally been shown in the I-O accounts. In the integrated accounts, the inventory valuation adjustment is treated as a secondary product produced by industries and included in their gross output, as well as a separate commodity going to final demand. The level of detail shown in table B applies to both industries and commodities and serves as the publication level of detail. Most of the estimation procedures, however, are applied at a finer level of industry and commodity detail in order to ensure the best estimates at the publication level.

\section{IV.2 Step 2: Revised 1997 Benchmark I-O Accounts}

The second step in the partial integration process is to revise the previously published 1997 benchmark I-O accounts, because it must provide the relationships and levels for integrating the annual I-O accounts and GDP-by-industry accounts. The 
necessary revisions are from two sources. First, the 1997 benchmark I-O accounts must be modified to incorporate the definitional, methodological, and statistical changes from the 2003 comprehensive revision of the NIPAs. Incorporating these changes ensures that the integrated accounts for 1998-2002 are consistent with the levels and composition of GDP in the NIPAs. The major NIPA changes and their effects on the 1997 benchmark I$\mathrm{O}$ accounts are summarized in table $\mathrm{C}$.

Second, after the NIPA revisions are incorporated, the level and the composition of value added for each industry must be further modified on the basis of information from both the I-O accounts and the GDP-by-industry accounts. ${ }^{13}$ As discussed above, value added by industry in the I-O accounts is computed as the difference between gross output and intermediate inputs by industry, and value added by industry in the GDP-byindustry accounts is computed from the industry distributions of GDI from the NIPAs. In general, these two measures of value added for an industry will differ (see the first two columns of table D). ${ }^{14}$

Chart 4 shows a matrix that demonstrates how the quality of the value added by industry estimates varies across the benchmark I-O accounts and the GDP-by-industry accounts. For example, both the benchmark I-O accounts and the GDP-by-industry accounts provide good measures of value added for the health care industry because of the near-complete coverage of gross output and intermediate inputs by the economic

\footnotetext{
${ }^{13}$ The GDP-by-industry value added that is based on the NIPA GDI estimates will also incorporate the results from the 2003 comprehensive NIPA revision.

${ }^{14}$ Research indicates that the magnitude and sign of these differences vary across industries and across time. For example, using data for 1992, Yuskavage (2000) finds that the property-type income for the manufacturing sector is, on average, lower in the GDP-by-industry accounts than in the benchmark I-O accounts. However, more recent research, using data for 1997, finds that the reverse is true; for the manufacturing sector, the gross operating surplus from the GDP-by-industry accounts is, on average, larger than the gross operating surplus from benchmark I-O accounts. BEA is continuing its research into the sources of these differences.
} 
census and the relatively small amount of redistributions of income resulting from enterprise-establishment adjustments. On the other hand, both sets of accounts provide poor measures for the construction industry because of incomplete coverage in the economic census and because of large, lower-quality, enterprise-establishment adjustments. For many industries, the quality of industry value added is mixed. Mining value added, for example, is good in the benchmark I-O accounts because of nearcomplete industry coverage, yet poor in the GDP-by-industry accounts because of relatively very large enterprise-establishment adjustments. The partial integration methodology draws the best information from both sets of accounts into a single, “combined" estimate of value added for each industry. These combined measures are then incorporated into the 1997 benchmark I-O accounts. ${ }^{15}$

The combined value added for an industry is an average with weights determined by criteria that reflect the relative quality of value added from the two sets of accounts. In general, these criteria are based on the quality of the source data used for each. The criteria for the benchmark I-O accounts include the following:

- The percent of intermediate inputs by industry that are covered by source data from the quinquennial economic census, and

- the percent of an industry's total gross output that is accounted for by the quinquennial economic census.

The criteria for the GDP-by-industry accounts include the following:

\footnotetext{
${ }^{15}$ The estimates of "compensation of employees" and "taxes on production and imports, less subsidies" in the revised 1997 benchmark I-O accounts are consistent with those published in the NIPAs. For censuscovered industries, the compensation in the previously published 1997 benchmark I-O accounts was based on the 1997 Economic Census. See Lawson, et al. (2002), p. 31.
} 
- The quality and the size of adjustments used to convert the enterprise-based, profit-type income data to an establishment basis, and

- the percent of an industry's value added that is accounted for by proprietors' income.

For both the benchmark I-O accounts and the GDP-by-industry accounts, these criteria, along with expert analyst judgment, are applied at the industry level shown in table B in order to identify point estimates and estimates of variance for each industry's measure of value added. ${ }^{16}$ These point estimates and estimates of variance are used to develop a probability distribution of value added for each industry from each set of accounts. Each probability distribution represents a measure of the likelihood that the “true” value added takes on a particular value, given the information available. The distributions are then combined to produce a measure of value added for each industry. Essentially, the combined measure is an average of the two point estimates with the weights being determined by the relative variances--that is, a point estimate with a smaller variance receives a larger weight. Appendix A provides technical details on the procedures used.

Chart 5 gives an example of this process for the educational services industry. The point estimate of value added is $\$ 63.4$ billion from the revised 1997 benchmark I-O accounts and $\$ 61.3$ billion from the GDP-by-industry accounts. The benchmark I-O value-added estimate reflects only a limited amount of information on this industry's

\footnotetext{
${ }^{16}$ The estimates are prepared at this level of detail because the industry distributions of GDI are available at this level. These estimates are allocated to more detailed industries when the revised benchmark I-O table is balanced. Source data for 1997 were not available on the 1997 North American Industry Classification System (NAICS) basis for all of the components of GDI. For selected components, BEA converted data from the 1987 Standard Industrial Classification (SIC) basis to the 1997 NAICS basis.
} 
gross output and intermediate inputs, because most establishments classified in this industry are out-of-scope of the quinquennial economic census. Therefore, the information used to prepare the I-O estimates was drawn from a variety of sources, including trade association data. The quality of these data is not as high as data from the economic census. In contrast, the GDP-by-industry value-added estimate reflects relatively complete data, based on the industry distributions of GDI from the NIPAs. Nevertheless, examining the two quality criteria for the GDP-by-industry accounts reveals that proprietors' income for this industry is about 3 percent of total value added and that the amount of adjustment required to convert enterprise-based profit-type income data to an establishment basis is about 1 percent. This implies that the combined estimate should be close, but not equal to, the GDP-by-industry point estimate.

A more formal analysis of the educational services industry is shown in chart 5, which includes the related probability distributions for each of the two point estimates. Note that the GDP-by-industry distribution is more peaked (smaller variance) than the distribution from the I-O accounts (larger variance). The smaller variance reflects a relatively good GDP-by-industry estimate; the larger variance for the benchmark I-O accounts reflects a relatively lower quality estimate. As expected, the combined estimate of $\$ 62.2$ billion is closer to the GDP-by-industry estimate than to the I-O estimate; the GDP-by-industry estimate is given a weight of about 57 percent, while the I-O estimate is given a weight of about 43 percent. Because more information is used to make this combined estimate, its overall quality is higher than that for either of the individual estimates, as shown by their distributions in chart 5. A complete list of the combined estimates of value added by industry is shown in the third column of table D. 
After the two sets of revisions have been made to the 1997 benchmark I-O accounts, it is then balanced. For this balancing, each industry's gross output and new measure of value added are fixed, and its total intermediate inputs is allowed to adjust to the difference. Balancing ensures that the use of commodities equals their supply, the sum of each industry's value added and intermediate inputs equals its gross output, and the sum of final uses equals published GDP. The revised and balanced 1997 benchmark I-O accounts then provide a starting point for preparing the integrated accounts for 19982002.

\section{IV.3 Step 3: A Time Series of Value Added for 1998-2002}

A time series of value added by industry is prepared by extrapolating the revised 1997 benchmark I-O estimates of value added by industry forward to 1998-2002, using the GDI-based measure of value added from the GDP-by-industry accounts as the extrapolator for each industry. The integrated industry accounts for 1998-2002 are presented on the 1997 NAICS basis. ${ }^{17}$ The components of GDI that compose value added by industry and information on the major source data and on the industrial distribution for each component are shown in table E.

As discussed above, the quality of the GDI-based measures of value added depends on a number of factors, including the size of adjustments required to convert enterprise-based, profit-type GDI data to an establishment basis and the size of proprietors' income. Nonetheless, they are preferred as growth indicators when compared with those from the annual I-O residual methodology because of the scarcity of annual data on intermediate inputs for credible measures of value added.

\footnotetext{
${ }^{17}$ For earlier years, GDP-by-industry estimates are available currently on a 1987 SIC basis only. BEA is currently conducting research on methods to extend the GDP-by-industry estimates backwards for years prior to 1998 on the 1997 NAICS basis.
} 
After extrapolating the revised 1997 benchmark I-O level of value added forward with the GDI-based measure for each industry, the resulting sum of value added across industries will not necessarily sum to GDP in a given year--part of the difference being the statistical discrepancy and the other part being extrapolation errors. ${ }^{18}$ This procedure allocates this difference in two steps. In the first step, expert analyst judgment is used to adjust some industries with known measurement problems. In the second step, the remaining difference is distributed across industries in proportion to the industries' value added.

\section{IV.4 Step 4: Updated and Balanced Annual I-O Accounts for 1998-2002}

Five tasks must be completed sequentially to update and balance each of the five annual I-O tables for 1998-2002. These tasks include (1) estimating gross output for each industry and commodity; (2) estimating the commodity composition of intermediate inputs for each industry; (3) estimating the domestic supply for each commodity; (4) incorporating estimates of commodities used for personal consumption, for gross private fixed investment, and for government consumption and investment as part of GDP finaldemand expenditures; and (5) balancing the use of commodities with available supply and the output of industries with necessary inputs for production.

\section{IV.4.a Industry and Commodity Gross Output}

For most industries and commodities, annual source data are available to estimate current-year industry and commodity gross output. The data sources used are shown in Table F. Manufacturing, trade, and most service industry estimates are based on annual

18 BEA also investigated using gross output by industry as an extrapolator for the revised 1997 benchmark I-O value added. This procedure-which assumes industry input-output ratios are constant over time-was not adopted, because tests on historical data showed that it yields larger discrepancies between the sum of extrapolated value added and GDP relative to GDI extrapolation. 
survey data from the Bureau of the Census. Agriculture, insurance, and government enterprise estimates, as well as transportation, utilities, finance, and real estate estimates, are primarily based on data from other government statistical agencies and private sources. For those industries and commodities for which annual source data are not available at the 1997 benchmark I-O level of detail, more aggregated source data are used as extrapolators.

\section{IV.4.b Intermediate Inputs to Industries}

Industry inputs are estimated in three steps. First, for domestic inputs, each industry's current-year output is valued in terms of the previous year's prices, using an industry price index that is calculated--in a Fisher index-number formula--as a weighted average of the price indexes for commodities produced by the industry. Estimates of inputs from foreign sources are revalued using import price indexes. For commodities for which a price index is unavailable, an aggregate price index is applied to multiple commodities. The data sources used to prepare these indexes are shown in table F.

Second, each industry's current-year output, valued in the prices for the previous year, is multiplied by the previous year's direct requirements coefficient for the same industry. The initial set of coefficients used are from the revised 1997 benchmark I-O accounts. The result of this multiplication yields current-year intermediate inputs valued in the prices of the previous year. ${ }^{19}$ At this point, the composition of an industry's inputs per dollar of output (valued in the prices of the previous year) is unchanged from that of the previous year. To adjust for changes in relative prices, the results are reflated to current-year prices, using the commodity price indexes.

\footnotetext{
${ }^{19}$ A direct requirements coefficient represents the amount of a commodity required by an industry to produce a dollar of the industry's output.
} 
Finally, commodity taxes, transportation costs, and trade margins for each intermediate input are estimated. Commodity taxes are added to increase the value of intermediate inputs from basic prices to producers’ prices, and transportation costs and trade margins are added to increase the value further to purchasers' prices. ${ }^{20}$ Estimates for commodity taxes and total transportation costs and margins are developed as part of the annual estimates of commodity gross output and are distributed to transactions using 1997 benchmark I-O relationships.

\section{IV.4.c Domestic Supply}

The domestic supply is estimated. The domestic supply of each commodity is the total value of goods and services available for consumption as intermediate inputs by industries or for final use as personal consumption, private fixed investment, and government consumption and gross investment. It is calculated as domestic commodity output, plus government sales, and imports less exports and change in private inventories. Imports and exports are based on foreign trade statistics from the Bureau of the Census and on BEA's international transactions accounts. Changes in private inventories are from the NIPAs and the commodity composition of inventories held by industries is based on relationships from the revised 1997 benchmark I-O accounts.

\section{IV.4.d Commodity Composition of Final Uses excluding Imports and Exports and Changes in Private Inventories}

The annual estimates of the major expenditure components of final uses for personal consumption, private fixed investment, and government consumption and gross investment are obtained directly from the NIPAs. The initial commodity compositions of

\footnotetext{
${ }^{20}$ The basic price is the price received by the producer for goods sold; it excludes the taxes collected by the producer from purchasers, as well as transportation costs and trade margins.
} 
these components are estimated using relationships from the revised 1997 benchmark I-O accounts.

\section{IV.4.e Balancing the Use Table}

Finally, commodities and industries are brought into balance using a biproportional adjustment procedure. This procedure sequentially adjusts rows and columns to equal the estimated output control totals. The adjustments are made iteratively until the use of each commodity equals its domestic supply, the sum of value added and intermediate inputs for each industry equals its gross output, and final-demand expenditures equal levels in the NIPAs. Unlike many I-O balancing systems, the system employed for the annual I-O tables takes advantage of the very detailed relationships included in the 1997 benchmark I-O accounts and balances in both producers’ and purchasers’ prices. The system balances approximately 3,000 rows and 1,200 columns while maintaining information on transportation costs and margins for each transaction. Appendix B provides a more detailed discussion of the techniques used for this balancing.

The annual I-O accounts are finalized for 1998-2002 after the results have been reviewed and verified. The measures of gross output, intermediate inputs, and value added by industry are then incorporated into the GDP-by-industry accounts.

\section{IV.5 Step 5: Price and Quantity Indexes for the GDP-by-Industry Accounts}

Price and quantity indexes for the GDP-by-industry accounts are prepared in two steps. First, price and quantity indexes for gross output and intermediate inputs are prepared for each industry. Second, information on gross output by industry is combined 
with information on intermediate inputs by industry to derive price and quantity indexes for value added by industry, using the double-deflation procedure.

\section{IV.5.a Indexes for Gross Output and Intermediate Inputs by Industry}

Price and quantity indexes for gross output by industry are derived by separately deflating each commodity produced by an industry and included in its gross output. Information on the commodities produced by industries is obtained from annual I-O make tables. Price and quantity indexes for intermediate inputs are estimated by deflating the commodities used by industries from the annual I-O use tables. The commodity price indexes used for this deflation are listed in table F. When a commodity price index is based on more than one detailed price index, a Fisher index-number formula is used to prepare the composite index. Appendix C "Computing Chain-Type Price and Quantity Indexes in the GDP-by-Industry Accounts” shows the Fisher indexnumber formulas that are used to prepare the price and quantity indexes for gross output and intermediate inputs by industry.

\section{IV.5.b Indexes for Value Added by Industry}

Price and quantity indexes for value added by industry are calculated using the double-deflation method. In the double-deflation method, separate estimates of gross output and intermediate inputs by industry are combined in a Fisher index-number formula in order to generate price and quantity indexes for value added by industry (see Appendix C). This method is preferred for computing price and quantity indexes for value added by industry because it requires the fewest assumptions about the relationships among gross outputs. 


\section{Future Research}

There are several areas of research that must be addressed in order to achieve BEA's long-run goal of full integration of the accounts. The most important of these include:

- Additional evaluation of the coverage, quality, and consistency of data from different sources for the purpose of improving BEA's industry accounts overall and its estimates of value added by industry specifically. This includes working cooperatively with other statistical agencies for the purpose of collecting additional data as well as expanding data sharing initiatives to address differences across alternative data sources.

- Related research to determine the underlying reasons for the discrepancies that existed between the GDP-by-industry and I-O levels of value added prior to setting a "combined" level for the integrated accounts. The fact that these discrepancies were clearly evident prior to the integration indicates underlying inconsistencies in source data and methodologies that need to be explored further. This research will also require working cooperatively with the statistical agencies providing the source data.

- Continued research to develop new methods and data sources that improve measures of gross operating surplus and direct measures of value-added-byindustry that are consistent with establishment-based definitions for industries. This is in contrast to the method of estimating value added as a residual resulting from intermediate purchases being subtracted from gross output. Although this 
method results in consistent estimates, it also picks up statistical errors that do not have anything to do with value added.

- Development of additional procedures to incorporate new data from the 2002 Economic Census and annual surveys of intermediate inputs by industry into BEA's industry accounts on a more accelerated basis, including techniques for evaluating "best-level" estimates as compared to "best-change" estimates.

- Development of new processes and procedures for incorporating information from the production-based approach of measuring GDP into the NIPAs on a timely basis.

- Extension of the NAICS-based industry accounts backwards for years prior to 1998. For the period 1947-86, research is underway to develop current-dollar GDP-by-industry estimates for broad industry groups. ${ }^{21}$ Additional research is needed to create current-dollar annual I-O tables for years prior to 1998.

\footnotetext{
${ }^{21}$ In November 2004, BEA published the NAICS-based GDP-by-Industry Accounts for the period 1987-
} 97. See Yuskavage and Pho. 


\section{Appendix A: Estimating the “Combined” Level of Value Added by Industry}

This appendix describes the procedure used to determine the "combined" estimates of value added by industry that are incorporated into the revised 1997 benchmark input-output (I-O) accounts. The procedure allows for the best information from both the I-O accounts and the Gross-Domestic-Product (GDP)-by-industry accounts to be used in determining the combined estimates. This is accomplished by preparing a weighted average of the two independent measures of value-added where the weights reflect the relative quality of the two measures. For each of the 61 industries presented in table $\mathrm{B}$, a weighted average is given by

$$
\text { Combined }_{\mathrm{i}}=b_{i, \mathrm{I}-\mathrm{O}}\left(\mathrm{I}-\mathrm{O}_{\mathrm{i}}\right)+b_{i, \mathrm{GDP} \text { by Industry }}\left(\mathrm{GDP} \text { by } \text { Industry }_{\mathrm{i}}\right) \text {, }
$$

where $\left(\mathrm{I}-\mathrm{O}_{\mathrm{i}}\right)$ is industry i’s point estimate of value added from the benchmark I-O accounts and (GDP by Industry ${ }_{i}$ ) is industry i's point estimate from the GDP-by-industry accounts. $b_{i, I-O}$ and $b_{i, G D P}$ by Industry are the weights for the benchmark I-O accounts and the GDP-by-industry accounts, respectively.

In this linear combination, the weights are a simple function of the relative precision of each point estimate. A modeling framework is developed to estimate the precision of each industry's value-added estimator. The precision of each point estimate is summarized using two measures. First, an ordinal quality ranking of industries is developed for both the benchmark I-O accounts and the GDP-by-industry accounts. Second, an approximate 95-percent confidence interval for each point estimate is determined by evaluating the uncertainty in the underlying source data. Implicit in both 
the ordinal ranking and the confidence intervals are the quality criteria outlined on page 19 of the main text. A review of these criteria suggests that a significant amount of expert analyst judgment is incorporated into this framework.

Two practical considerations constrained the modeling framework finally selected by BEA for estimating weights. First, the overall objective is to obtain the most accurate weighted average feasible from the information currently available. Second, the model must not be overly sensitive to misspecifications of the 95- percent confidence intervals.

The chosen model requires the following assumptions:

1. Information about each benchmark I-O and GDP-by-industry value-added estimate can be effectively summarized by estimating the mean and standard deviation of a normal distribution. (This assumption implies that the standard deviation accurately summarizes the uncertainty associated with each estimator.)

2. The relative quality of the estimates from the benchmark I-O accounts and the GDP-by-industry accounts can be evaluated based on their point estimate-tostandard deviation ratios.

3. The point estimate-to-standard deviation ratios for all industries can be represented by an ordered vector with elements sampled from a beta distribution.

The steps for estimating each industry's standard deviation are as follows (for illustrative purposes, only the benchmark I-O accounts are discussed but the process is performed on the GDP-by-industry accounts as well): 
1. For the benchmark I-O accounts, set candidate values for the two parameters of the beta distribution as a starting point. This distribution is evaluated as a candidate for characterizing the underlying distribution of point estimate-tostandard deviation ratios for all industries in the benchmark I-O accounts.

2. Sample 61 values from the distribution from step 1 .

3. Rank order the 61 values from step 2 and assign one to each benchmark industry based on its ordinal ranking.

4. For each industry, use the assigned point estimate-to-standard deviation ratio and the known point estimate to determine the implied standard deviation--that is, solve the following equation for industry i’s standard deviation.

$$
\text { Error Metric }_{i}=\left(\text { Standard Deviation }_{i}\right) /\left(\text { Point Estimate }_{i}\right) \text {. }
$$

5. Repeat this process many times (on average, about 5000 times), storing the implied standard deviations of the industry estimators from each repetition.

6. Compute the average of the sampled standard deviations for each industry using the results from step 5; use this average to develop a 95-percent confidence interval based on the normal distribution—-that is,

$$
\text { N(Point Estimate, Average Standard Deviation). }
$$

7. Compare the upper and lower bounds of the confidence interval estimated in step 6 with the original 95-percent confidence interval estimated for the benchmark IO accounts.

8. Repeat steps 1 through 7 with all candidate beta parameters. Find the beta parameters that minimize the sum of squared deviations between the 95-percent confidence intervals from the benchmark I-O accounts and those from step 6. 
9. After estimating the beta parameters from step 8, follow steps 2 through 6 to estimate the standard deviation for each of the 61 industries in the benchmark I-O accounts.

This procedure approximates the estimator variance for each benchmark I-O and GDP-by-industry value-added estimate. The estimator variance estimates are used to determine the weights for the combined estimates. Estimators with smaller variances are given greater weight, that is to say, the following weights are used to estimate the combined level of value added for each industry:

$b_{i, \mathrm{I}-\mathrm{O}}=\frac{\sigma_{i, \mathrm{GDP} b t \text { Industry }}^{2}}{\sigma_{i, \mathrm{GDP} \text { b t ndustry }}^{2}+\sigma_{i, \mathrm{I}-\mathrm{O}}^{2}}$ and $b_{i, \mathrm{GDP} \text { by Industry }}=\frac{\sigma_{i, \mathrm{I}-\mathrm{O}}^{2}}{\sigma_{i, \mathrm{GDP} b \mathrm{Industry}}^{2}+\sigma_{i, \mathrm{I}-\mathrm{O}}^{2}}$ 


\section{Appendix B: New Updating and Balancing Processes for BEA's Annual I-O Tables}

Since 1999, when the Bureau of Economic Analysis (BEA) reinstated its annual input-output (I-O) program beginning with the release of accounts for 1996, BEA has had among its many goals that of releasing annual I-O tables on a schedule synchronized with that for the GDP-by-industry accounts. To achieve this goal implies regularly providing a time series of annual I-O tables with those for the most recent years being updated and revised through the standard advance, preliminary, and final iterations—a potentially very resource-intensive process.

The five broad tasks required to produce annual I-O tables were identified and discussed in the main body of this report (see section III, step 4, beginning on page 21). In evaluating likely prospects for increased automation, BEA focused on task 5, "balancing the use table," which has tended to be very labor intensive because of BEA's extensive use of hand adjustments for the process. This appendix summarizes the results of BEA's research in this area and describes the changes being incorporated into the current balancing procedures for the 1998-2002 annual I-O accounts. ${ }^{1}$

The appendix is divided into three sections. The first section describes BEA's new balancing procedure. The second section describes the different tests that BEA performed on this procedure before it was adopted. The third section provides summary remarks.

\footnotetext{
${ }^{1}$ For further information on this research, see the paper, "Increasing the Timeliness of U.S. Annual I-O Accounts," by M. Planting and J. Guo, in Economic Systems Research, No. 2, Vol. 16, 2004. The complete paper can also be obtained from BEA's Web site at http://www.bea.gov/bea/papers/Timeliness.pdf.
} 


\section{Expanded Automation of Balancing Procedures}

BEA has developed a new set of automated procedures for balancing its time series of integrated annual I-O tables for 1998 to 2002. Consistent with the research results, the new balancing procedures:

- Are based on an adjusted RAS (bi-proportional) process;

- balance the I-O table in producers’ and purchasers’ prices simultaneously;

- incorporate more exogenous data; and

- process the tables at the most detailed level of data feasible.

The new procedures generally begin with an I-O use table that has been updated, following steps one through four described in the main body of this report. The I-O use table matrix is then balanced in both basic prices and purchasers' prices. (The purchasers' price equals the basic price plus commodity taxes, transportation costs, and margin costs.) This process allocates transportation costs and margin costs to industries and final uses as functions of how the commodities are moved by the economy's transportation system (rail, truck, water, air, pipeline, and gas pipeline) and through its distribution channels (wholesale trade and retail trade). In the use table, these costs are summed for each industry and shown as separate commodity purchases.

The new balancing procedures require fifteen matrices, each of which must be balanced internally, while maintaining the different relationships specified among matrices. The following matrices are prepared: A matrix with commodities valued in basic prices and one in purchasers' prices; one for commodity taxes; one for each of the six transportation modes (rail, truck, water, air, oil pipe, and gas pipe); one for wholesale trade margin; one for retail trade margin; and two matrices for taxes by each type of 
margin (see Figure 1). The transportation and wholesale trade matrices are of the same dimensions as those for producers' and purchasers' prices. The retail trade matrix is a single vector with one margin total for all consuming industries and final users. The matrix valued in basic prices is related to that valued in purchasers' prices through the taxes, transportation, and trade matrices. A cell in the purchasers' value matrix equals the corresponding cell in the basic value matrix plus the cells in the taxes, transportation and trade matrices; conversely, a cell in the basic value matrix equals the corresponding cell in the purchasers' value matrix less those in the taxes, transportation and trade matrices.

Control totals are identified for each matrix. The basic price, tax, transportation, and trade matrices are two dimensional and have separate control totals for each row or commodity. The retail trade margin matrices are one dimensional and have single control totals for the margin, sales tax, and other retail tax. The purchasers' price matrix is two dimensional and is the sum of producers' price inputs plus transportation and trade margin costs; it has column control totals for each industry and final use category.

Detailed national income and product accounts (NIPA) estimates, in purchasers' prices, are used as controls for the different types of final uses. These detailed data provide the basis for expanding estimates of personal consumption expenditures from one to 210 categories; gross private fixed investment from one to 33; structures, from one to 26; and government expenditures and investment from six to 136. Elements that remain constant or fixed in all matrices include exports, imports, changes in business inventories, and other negative cells. 
Balancing the fifteen matrices is complex and requires several steps and iterations. Beginning first with the rows, adjustment factors are calculated, equaling the row control less the sum of the fixed cells in the row, divided by the sum of the new cells less the fixed cells. These adjustment factors are applied to the row cells that are not fixed in each matrix. The purchasers' price matrix is then calculated as the sum of the twelve other matrices. To balance the columns, adjustment factors are again calculated, this time equaling the column control less the sum of the fixed cells in the column, divided by the sum of the column cells less the fixed cells. These factors are then applied to the column cells that are not fixed in each matrix. The cells in the basic price matrix are then calculated as the difference between the purchasers' price and the sum of the twelve other matrices.

After a set number of iterations, and when the cells are close to being balanced in both basic and purchasers' values, then the taxes, transportation, and trade matrices are forced to also balance to their respective row control totals. The balancing of the taxes, transportation, and trade matrices is delayed until the matrices valued in basic and purchasers' prices are approximately balanced in order to maintain the initial tax rates, transportation cost rates, and trade margin rates as long as possible.

\section{Tests on the New Procedures}

BEA tested both the new balancing procedures and an alternative, more highlyautomated set of procedures, referred to as a "basic model," using an old workfile with 1997 detailed data. Results were then compared to the published 1997 annual I-O use table. Unlike the new procedures which balance multiple matrices, the basic model balances the table in producers' prices only. To evaluate the results from the two 
approaches, a set of tests were designed to answer the following questions:

- Does balancing in both producers' and purchasers' prices improve results? Most I-O tables are balanced in producers’ prices (basic model). However, balancing in producers' prices ignores the detailed estimates of final use expenditures from the NIPAs, which are valued in purchasers' prices as well as the relationships between transportation and margin costs and the use of goods. It is hypothesized that valuing in purchasers' prices and using detailed data from the NIPAs improve the reliability of the balancing model.

- Does the addition of known estimates of value added for industries improve results? Value added makes up a significant portion of each industry’s input structure. It is hypothesized that providing estimates of value added for industries significantly reduces necessary adjustments and improves overall results. (Value added is determined endogenously as a residual for the basic model.)

- Does greater industry and commodity detail improve the results? The more aggregated the table, the more diverse the mix of products grouped together as a single commodity and the more diverse the market. Conversely, the more disaggregated the table, the more specialized commodities are to different markets. It is hypothesized that using more detail at the working level improves the initial distributions of commodities to users and, consequently, also improves the reliability of the balancing model.

To answer these questions, BEA designed twelve tests that could be used to compare results from the new procedures with those from the basic model. Each version of a use table was balanced, using both the new adjustment process and the basic 
adjustment process. For the balancing, each was run through 40 iterations. Each final use table was then collapsed to the summary level and compared to the published 1997 annual I-O use table.

The measure used for comparing results is the direct coefficient- that is, the amount of a commodity required by an industry to produce a dollar of output. The fewer the differences in direct coefficients between the balanced tables and the published 1997 annual table, the better the balancing model. Our comparisons were limited to the larger cells of the use table, that is, to direct coefficients with underlying intermediate values of \$100 million or greater in producers’ prices, and to those cells with absolute value difference (published less the balanced direct coefficient) of greater than 0.01 for direct coefficients.

Table 1 provides the major test results. Overall, large coefficient differences decreased from 11.7 percent for the basic model, balanced at the publication level of data and using value added calculated as a residual, to 5.8 percent for the new model, balanced at the source data level and using independent, fixed value-added estimates. The major conclusions from the tests are as follows:

- Results from the new balancing procedures are better than those from the basic model;

- $\quad$ working with more detail data improves results;

- the addition of known value-added estimates improves results; and

- the new balancing procedures result in only 5.8 percent of the direct coefficients changing by more that 0.01 with a absolute average change of 0.029 . 


\section{Conclusions}

One of BEA’s goals has been to develop the capability for producing I-O tables that are more current but are not extremely resource intensive to produce. Research to this end has resulted in BEA's development of new automated procedures for balancing its use tables. From the test results examined, it is concluded that the best results are obtained when balancing in both purchasers' and basic prices. The test results also show that providing fixed estimates of value added and working at the detailed source data level both improve final results. However, although the new procedures produce use tables that are fairly comparable to the published table, the remaining differences are still important. Additional research is needed to evaluate these remaining coefficient differences and their causes. 
Table 1. Large Coefficient Differences from the New Balancing Model Compared with those from the Basic Balancing Model ${ }^{1}$

\begin{tabular}{|c|c|c|c|c|}
\hline Model & $\begin{array}{l}\text { Balancing } \\
\text { level }\end{array}$ & $\begin{array}{l}\text { Value } \\
\text { added }\end{array}$ & $\begin{array}{l}\text { Percent of } \\
\text { cells } \\
\text { with large } \\
\text { coefficient } \\
\text { differences }\end{array}$ & $\begin{array}{c}\text { Mean } \\
\text { absolute } \\
\text { value of } \\
\text { coefficient } \\
\text { difference }\end{array}$ \\
\hline \multirow{4}{*}{ Basic } & \multirow{2}{*}{$\begin{array}{c}\text { Detailed } \\
\text { publication level }\end{array}$} & Residual & 11.7 & 0.027 \\
\hline & & Fixed & 9.8 & 0.025 \\
\hline & \multirow{2}{*}{$\begin{array}{c}\text { Source data } \\
\text { level }\end{array}$} & Residual & 8.3 & 0.030 \\
\hline & & Fixed & 6.5 & 0.028 \\
\hline \multirow{4}{*}{ New } & \multirow{2}{*}{$\begin{array}{c}\text { Detailed } \\
\text { publication level }\end{array}$} & Residual & 7.3 & 0.032 \\
\hline & & Fixed & 9.6 & 0.027 \\
\hline & \multirow{2}{*}{$\begin{array}{c}\text { Source data } \\
\text { level }\end{array}$} & Residual & 7.3 & 0.033 \\
\hline & & Fixed & 5.8 & 0.029 \\
\hline
\end{tabular}

${ }^{1}$ Large coefficient differences are defined as those greater than 0.01 from the same cell in the published 1997 I-O use table. 
Figure 1. Relationship between Basic Value and Purchasers’ Value Matrices in the New Balancing Model

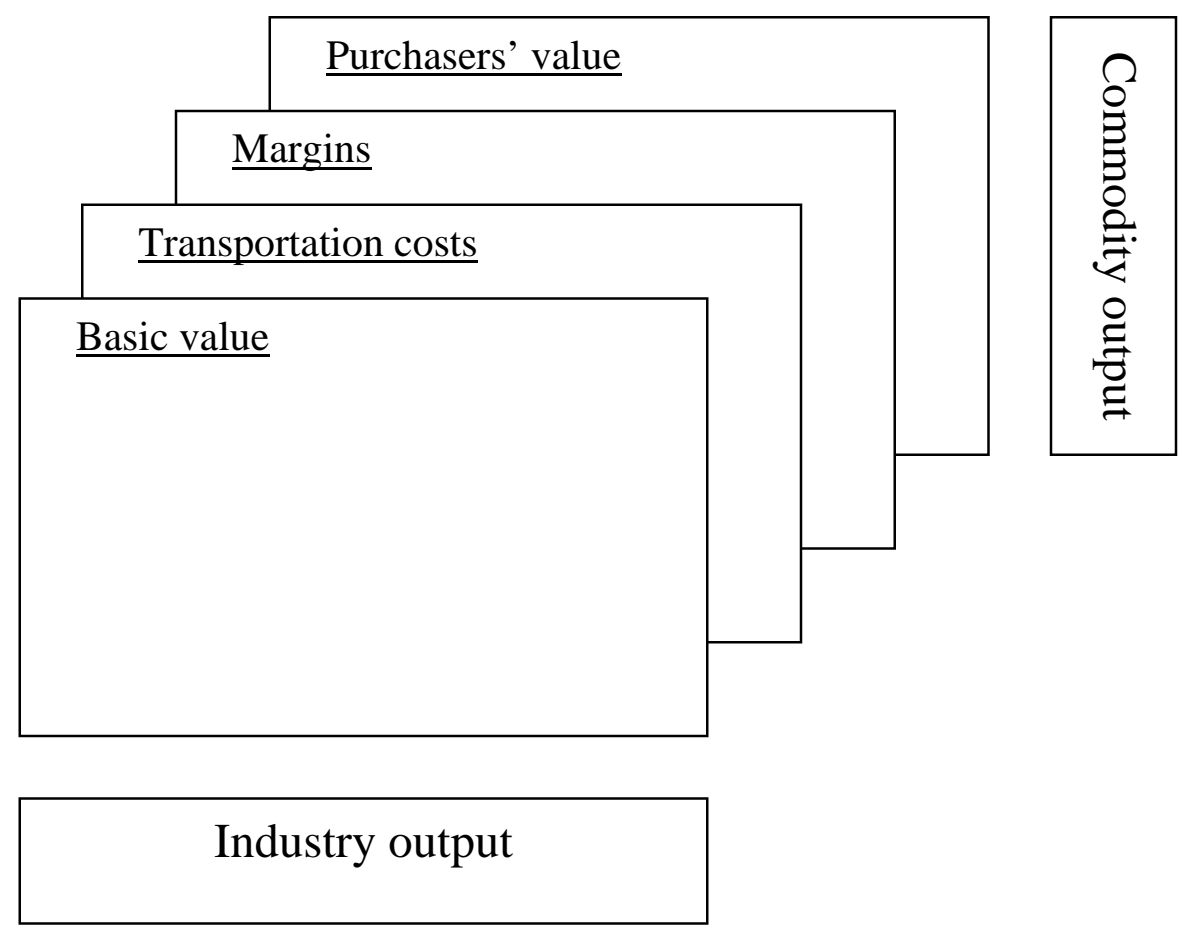




\section{Appendix C: Computing Chain-Type Price and Quantity Indexes in the GDP-by- Industry Accounts}

The computation of the chain-type Fisher price and quantity indexes for gross output, intermediate inputs, and value added for an industry or an aggregate is summarized below. The value-added price index for an industry represents the price of its primary factors of production-that is, it represents the price of capital and labor used in the production of gross output. Similarly, the value-added quantity index for an industry represents the quantity of capital and labor used in the production of gross output.

\section{Chain-type price indexes}

In the notation, $L P_{t-1, t}$ refers to the Laspeyres price relative for the years $t-1$ and $t$, $\mathrm{PP}_{\mathrm{t}-1, \mathrm{t}}$ refers to the Paasche price relative, $\mathrm{FP}_{\mathrm{t}-1, \mathrm{t}}$ refers to the Fisher price relative, and $\mathrm{CP}_{\mathrm{t}}$ refers to the Fisher chain-type price index. The superscript GO refers to gross output, II refers to intermediate inputs, and VA refers to value added; p refers to detailed prices, and q refers to quantities.

Laspeyres price relatives for gross output, intermediate inputs, and value added, respectively, are:

$$
\begin{aligned}
L P_{t-1, t}^{G O} & =\frac{\sum p_{t}^{G O} q_{t-1}^{G O}}{\sum p_{t-1}^{G O} q_{t-1}^{G O}}, \\
L P_{t-1, t}^{I I} & =\frac{\sum p_{t}^{I I} q_{t-1}^{I I}}{\sum p_{t-1}^{I I} q_{t-1}^{I I}}, \text { and } \\
L P_{t-1, t}^{V A} & =\frac{\left(\sum p_{t}^{G O} q_{t-1}^{G O}\right)-\left(\sum p_{t}^{I I} q_{t-1}^{I I}\right)}{\left(\sum p_{t-1}^{G O} q_{t-1}^{G O}\right)-\left(\sum p_{t-1}^{I I} q_{t-1}^{I I}\right)} .
\end{aligned}
$$

Paasche price relatives for gross output, intermediate inputs, and value added are: 


$$
\begin{aligned}
P P_{t-1, t}^{G O} & =\frac{\sum p_{t}^{G O} q_{t}^{G O}}{\sum p_{t-1}^{G O} q_{t}^{G O}}, \\
P P_{t-1, t}^{I I} & =\frac{\sum p_{t}^{I I} q_{t}^{I I}}{\sum p_{t-1}^{I I} q_{t}^{I I}}, \text { and } \\
P P_{t-1, t}^{V A} & =\frac{\left(\sum p_{t}^{G O} q_{t}^{G O}\right)-\left(\sum p_{t}^{I I} q_{t}^{I I}\right)}{\left(\sum p_{t-1}^{G O} q_{t}^{G O}\right)-\left(\sum p_{t-1}^{I I} q_{t}^{I I}\right)} .
\end{aligned}
$$

Fisher price relatives for gross output, intermediate inputs, and value added are:

$$
\begin{aligned}
& F P_{t-1, t}^{G O}=\sqrt{L P_{t-1, t}^{G O} \times P P_{t-1, t}^{G O}}, \\
& F P_{t-1, t}^{I I}=\sqrt{L P_{t-1, t}^{I I} \times P P_{t-1, t}^{I I}}, \text { and } \\
& F P_{t-1, t}^{V A}=\sqrt{L P_{t-1, t}^{V A} \times P P_{t-1, t}^{V A}} .
\end{aligned}
$$

Fisher chain-type price indexes for gross output, intermediate inputs, and value added for years after the reference year are:

$$
\begin{aligned}
& C P_{t}^{G O}=C P_{t-1}^{G O} \times F P_{t-1, t}^{G O}, \\
& C P_{t}^{I I}=C P_{t-1}^{I I} \times F P_{t-1, t}^{I I}, \text { and } \\
& C P_{t}^{V A}=C P_{t-1}^{V A} \times F P_{t-1, t}^{V A} .
\end{aligned}
$$

In the reference year (2000 for this comprehensive revision),

$$
C P_{t}^{G O}=C P_{t}^{I I}=C P_{t}^{V A}=100 .
$$




\section{Chain-type quantity indexes}

In the notation, $\mathrm{LQ}_{\mathrm{t}-1, \mathrm{t}}$ refers to the Laspeyres quantity relative for the years $\mathrm{t}-1$ and $t, \mathrm{PQ}_{\mathrm{t}-1, \mathrm{t}}$ refers to the Paasche quantity relative, $\mathrm{FQ}_{\mathrm{t}-1, \mathrm{t}}$ refers to the Fisher quantity relative, and $\mathrm{CQ}_{\mathrm{t}}$ refers to the Fisher chain-type quantity index. The superscript GO refers to gross output, II refers to intermediate inputs, and VA refers to value added; $\mathrm{p}$ refers to detailed prices, and q refers to quantities.

Laspeyres quantity relatives for gross output, intermediate inputs, and value added, respectively, are:

$$
\begin{aligned}
L Q_{t-1, t}^{G O} & =\frac{\sum p_{t-1}^{G O} q_{t}^{G O}}{\sum p_{t-1}^{G O} q_{t-1}^{G O}}, \\
L Q_{t-1, t}^{I I} & =\frac{\sum p_{t-1}^{I I} q_{t}^{I I}}{\sum p_{t-1}^{I I} q_{t-1}^{I I}}, \text { and } \\
L Q_{t-1, t}^{V A} & =\frac{\left(\sum p_{t-1}^{G O} q_{t}^{G O}\right)-\left(\sum p_{t-1}^{I I} q_{t}^{I I}\right)}{\left(\sum p_{t-1}^{G O} q_{t-1}^{G O}\right)-\left(\sum p_{t-1}^{I I} q_{t-1}^{I I}\right)}
\end{aligned}
$$

Paasche quantity relatives for gross output, intermediate inputs, and value added are:

$$
\begin{aligned}
P Q_{t-1, t}^{G O} & =\frac{\sum p_{t}^{G O} q_{t}^{G O}}{\sum p_{t}^{G O} q_{t-1}^{G O}}, \\
P Q_{t-1, t}^{I I} & =\frac{\sum p_{t}^{I I} q_{t}^{I I}}{\sum p_{t}^{I I} q_{t-1}^{I I}}, \text { and } \\
P Q_{t-1, t}^{V A} & =\frac{\left(\sum p_{t}^{G O} q_{t}^{G O}\right)-\left(\sum p_{t}^{I I} q_{t}^{I I}\right)}{\left(\sum p_{t}^{G O} q_{t-1}^{G O}\right)-\left(\sum p_{t}^{I I} q_{t-1}^{I I}\right)}
\end{aligned}
$$

Fisher quantity relatives for gross output, intermediate inputs, and value added are: 


$$
\begin{aligned}
& F Q_{t-1, t}^{G O}=\sqrt{L Q_{t-1, t}^{G O} \times P Q_{t-1, t}^{G O}}, \\
& F Q_{t-1, t}^{I I}=\sqrt{L Q_{t-1, t}^{I I} \times P Q_{t-1, t}^{I I}}, \text { and } \\
& F Q_{t-1, t}^{V A}=\sqrt{L Q_{t-1, t}^{V A} \times P Q_{t-1, t}^{V A}} .
\end{aligned}
$$

Fisher chain-type quantity indexes for gross output, intermediate inputs, and value added for years after the reference year are:

$$
\begin{aligned}
& C Q_{t}^{G O}=C Q_{t-1}^{G O} \times F Q_{t-1, t}^{G O}, \\
& C Q_{t}^{I I}=C Q_{t-1}^{I I} \times F Q_{t-1, t}^{I I}, \text { and } \\
& C Q_{t}^{V A}=C Q_{t-1}^{V A} \times F Q_{t-1, t}^{V A} .
\end{aligned}
$$

In the reference year (2000 for this comprehensive revision),

$$
C Q_{t}^{G O}=C Q_{t}^{I I}=C Q_{t}^{V A}=100
$$




\section{References}

Lawson, Ann M. 2000. Current and Future Directions for the U.S. Industry Accounts. Paper presented at the 13th International Conference on Input-Output Techniques, Macerata, Italy, August 21-25. Available on the Internet at http://www.bea.gov/bea/papers/usindacc.pdf

Lawson, Ann M., Kurt S. Bersani, Mahnaz Fahim-Nader, and Jiemin Guo. 2002. "Benchmark Input-Output Accounts of the United States, 1997." Survey of Current Business 82 (December): 19-109. Available on the Internet at http://www.bea.gov/bea/ARTICLES/2002/12December/1202I-OAccounts2.pdf

Lawson, Ann, M., Sumiye O. Okubo, and Mark A. Planting. 2000. “Annual Input-Output Accounts of the United States, 1996." Survey of Current Business 80 (January): 37-86. Available on the Internet at http://www.bea.gov/bea/articles/NATIONAL/Inputout/2000/0100io.pdf

Lum, Sherlene K.S., Brian C. Moyer, and Robert E. Yuskavage. 2000. "Improved Estimates of Gross Product by Industry for 1947-98." Survey of Current Business 80 (June): 24-54. Available on the Internet at http://www.bea.gov/bea/articles/National/NIPAREL/2000/0600gpi.pdf

Moulton, Brent R. and Eugene P. Seskin. 2003. "Preview of the 2003 Comprehensive Revision of the National Income and Product Accounts: Changes in Definitions and Classifications." Survey of Current Business 83 (June): 17-34. Available on the Internet at http://www.bea.gov/bea/ARTICLES/2003/06June/0603NIPArevs.pdf

Moyer, Brian C., Mark A. Planting, Mahnaz Fahim-Nader, and Sherlene K.S. Lum. 2004. "Preview of the Comprehensive Revision of the Annual Industry Accounts." Survey of Current Business 84 (March): 38-51. Available on the Internet at http://www.bea.gov/bea/ARTICLES/2004/03March/0304IndustryAcctsV3.pdf

Moyer, Brian C., Mark A. Planting, Paul V. Kern, and Abigail Kish. 2004. "Improved Annual Industry Accounts for 1998-2003.” Survey of Current Business 84 (June): 21-57. Available on the Internet at http://www.bea.gov/bea/ARTICLES/2004/06June/0604GDP_Industry.pdf

Planting, Mark and Jiemin Guo. 2004. "Increasing the Timeliness of U.S. Annual I-O Accounts." Economic Systems Research, No. 2, Vol. 16. Available on the Internet at http://www.bea.gov/bea/papers/Timeliness.pdf

Planting, Mark A. and Peter D. Kuhbach. 2001. "Annual Input-Output Accounts of the U.S. Economy, 1998.” Survey of Current Business 81 (December): 41-70. 
Available on the Internet at

http://www.bea.gov/bea/ARTICLES/2001/12december/1201io98.pdf

Yuskavage, Robert E. 2000. Priorities for Industry Accounts at BEA. Paper presented at a meeting of the BEA Advisory Committee, November 17. Available on the Internet at http://www.bea.gov/bea/papers/priority.pdf

Yuskavage, Robert E. 2002. "Gross Domestic Product by Industry, A Progress Report on Accelerated Estimates." Survey of Current Business 82 (June): 19-27. Available on the Internet at http://www.bea.gov/bea/ARTICLES/2002/06June/0602GDPbyIndy.pdf

Yuskavage, Robert E. and Yvon H. Pho. 2004. "Gross Domestic Product by Industry for 1987-2000, New Estimates on the North American Industry Classification System." Survey of Current Business 84 (November): 33-53. Available on the Internet at http://www.bea.gov/bea/ARTICLES/2004/11November/1104GDP_by_Indy.pdf 
Table A1. Comparison of BLS and Census Nonagricultural Payroll Data for Selected Private Industries, 1992 I1/ [Millions of dollars unless otherwise noted]

\begin{tabular}{|c|c|c|c|c|}
\hline Industry description & BLS & Census & $\begin{array}{c}\text { BLS less } \\
\text { Census }\end{array}$ & $\begin{array}{c}\text { Absolute } \\
\text { percent } \\
\text { difference }\end{array}$ \\
\hline Total & $2,046,864$ & $2,020,570$ & 26,294 & 1.3 \\
\hline \multicolumn{5}{|c|}{ Industries with absolute difference of $\mathbf{1 0}$ percent or more } \\
\hline Membership organizations & 15,458 & 10,188 & 5,270 & 34.1 \\
\hline Tobacco products & 2,103 & 2,534 & -431 & 20.5 \\
\hline Miscellaneous repair services & 8,263 & 9,849 & $-1,586$ & 19.2 \\
\hline Health services & 236,388 & 278,598 & $-42,210$ & 17.9 \\
\hline Pipelines, except natural gas & 975 & 821 & 154 & 15.8 \\
\hline Motor freight transportation and warehousing & 35,536 & 41,070 & $-5,534$ & 15.6 \\
\hline Leather and leather products & 2,320 & 1,973 & 347 & 15.0 \\
\hline Security and commodity brokers and dealers & 39,908 & 34,390 & 5,518 & 13.8 \\
\hline Oil and gas extraction & 15,539 & 13,933 & 1,606 & 10.3 \\
\hline Insurance agents, brokers, and services & 21,327 & 19,123 & 2,204 & 10.3 \\
\hline Nondepository credit institutions & 15,007 & 16,509 & $-1,502$ & 10.0 \\
\hline
\end{tabular}

Industries with absolute difference of 5 to less than 10 percent

Real estate

Textile mill products

Transportation services

Water transportation

Industrial machinery and equipment

Social services

Retail trade

Holding and other investment offices

Transportation equipment

Paper and allied products

Amusement and recreation services

Motion pictures

Stone, clay, and glass products

Wholesale trade

\begin{tabular}{|r|r|r|r|}
\hline 29,634 & 26,817 & 2,817 & \\
14,801 & 13,531 & 1,270 & 9.5 \\
8,959 & 8,225 & 734 & 8.6 \\
5,949 & 5,481 & 468 & 8.2 \\
69,749 & 64,588 & 5,161 & 7.9 \\
27,508 & 25,565 & 1,943 & 7.4 \\
268,207 & 249,328 & 18,879 & 7.1 \\
10,313 & 9,626 & 687 & 7.0 \\
74,475 & 69,706 & 4,769 & 6.7 \\
24,542 & 23,079 & 1,463 & 6.4 \\
20,816 & 19,612 & 1,204 & 6.0 \\
9,611 & 10,160 & -549 & 5.8 \\
15,283 & 14,441 & 842 & 5.7 \\
199,687 & 188,780 & 10,907 & 5.5 \\
\hline
\end{tabular}

Industries with absolute difference of less than $\mathbf{5}$ percent

Primary metal industries

Lumber and wood products

Petroleum and coal products

Local and interurban passenger transportation

Rubber and miscellaneous plastics products

Food and kindred products

Automotive repair, services, and parking

Depository institutions

Fabricated metal products

Construction

Electric, gas, and sanitary services

Electronic and other electric equipment

Communications

Chemicals and allied products

Insurance carriers

Instruments and related products

Apparel and other textile products

Legal services

Nonmetallic minerals, except fuels

Printing and publishing

Business services

Furniture and fixtures

Miscellaneous manufacturing industries

\begin{tabular}{r|r|r|r|}
24,612 & 23,483 & 1,129 & \\
15,345 & 14,669 & 676 & 4.6 \\
7,568 & 7,246 & 322 & 4.4 \\
5,624 & 5,394 & 230 & 4.2 \\
24,058 & 25,028 & -970 & 4.1 \\
44,712 & 43,032 & 1,680 & 4.0 \\
17,207 & 16,597 & 610 & 3.8 \\
59,464 & 57,479 & 1,985 & 3.5 \\
39,745 & 40,929 & $-1,184$ & 3.3 \\
122,135 & 118,600 & 3,535 & 3.0 \\
40,683 & 39,623 & 1,060 & 2.9 \\
52,057 & 50,812 & 1,245 & 2.6 \\
48,908 & 47,742 & 1,166 & 2.4 \\
47,911 & 46,835 & 1,076 & 2.4 \\
49,457 & 50,559 & $-1,102$ & 2.2 \\
35,932 & 36,613 & -681 & 2.2 \\
16,792 & 16,506 & 286 & 1.9 \\
40,480 & 39,995 & 485 & 1.7 \\
3,291 & 3,265 & 26 & 1.2 \\
43,655 & 43,926 & -271 & 0.8 \\
115,010 & 114,446 & 564 & 0.6 \\
10,650 & 10,678 & -28 & 0.5 \\
9,210 & 9,189 & 21 & 0.3 \\
& & & 0.2 \\
& & &
\end{tabular}


Table A2. BLS and Census Nonagricultural Payroll Data for Private Industries: Comparison of Levels, 1992 and 1997

[Millions of dollars unless otherwise noted]

\begin{tabular}{|c|c|c|c|c|c|c|c|c|}
\hline \multirow[b]{3}{*}{ Industry description } & \multicolumn{2}{|c|}{ BLS } & \multicolumn{2}{|c|}{ Census /1/ } & \multicolumn{4}{|c|}{ Difference in Levels } \\
\hline & \multirow[b]{2}{*}{$\begin{array}{r}1992 \\
(\operatorname{col} 1) \\
\end{array}$} & \multirow[b]{2}{*}{$\begin{array}{r}1997 \\
(\mathrm{col} 2) \\
\end{array}$} & \multirow[b]{2}{*}{$\begin{array}{r}1992 \\
(\mathrm{col} 3) \\
\end{array}$} & \multirow[b]{2}{*}{$\begin{array}{r}1997 \\
(\operatorname{col} 4) \\
\end{array}$} & \multicolumn{2}{|c|}{1992} & \multicolumn{2}{|c|}{1997} \\
\hline & & & & & $\begin{array}{c}\text { In dollars } \\
(\mathrm{col} 5)= \\
(\mathrm{col} 1)-(\mathrm{col} 3) \\
\end{array}$ & \begin{tabular}{|c|} 
As percent \\
of Census level \\
$(\mathrm{col} 6)=$ \\
$(\operatorname{col} 5) /(\mathrm{col} 1)$ \\
\end{tabular} & $\begin{array}{c}\text { In dollars } \\
(\mathrm{col} 7)= \\
(\mathrm{col} 2)-(\mathrm{col} 4) \\
\end{array}$ & $\begin{array}{c}\text { As percent } \\
\text { of Census level } \\
(\mathrm{col} 8)= \\
(\operatorname{col} 7) /(\mathrm{col} \mathrm{2}) \\
\end{array}$ \\
\hline Total & $2,256,116$ & $3,034,863$ & /2/ & $2,911,663$ & $\ldots$ & $\ldots$ & 123,200 & 4.2 \\
\hline Mining & 26,372 & 29,785 & 24,906 & 26,857 & 1,466 & 5.9 & 2,928 & 10.9 \\
\hline Metal mining & 2,226 & 2,705 & $/ 2 /$ & 2,460 & $\ldots$ & $\ldots$ & 245 & 10.0 \\
\hline Coal mining & 5,317 & 4,694 & $/ 2 /$ & 4,535 & $\ldots$ & $\ldots$ & 159 & 3.5 \\
\hline Oil and gas extraction & 15,539 & 18,219 & 13,933 & 15,830 & 1,606 & 11.5 & 2,388 & 15.1 \\
\hline Nonmetallic minerals, except fuels & 3,291 & 4,167 & 3,265 & 4,032 & 26 & 0.8 & 135 & 3.3 \\
\hline Construction & 122,135 & 179,339 & 118,600 & 172,196 & 3,535 & 3.0 & 7,143 & 4.1 \\
\hline Manufacturing & 575,521 & 714,405 & 558,795 & 681,201 & 16,726 & 3.0 & 33,204 & 4.9 \\
\hline Food and kindred products & 44,712 & 52,574 & 43,032 & 50,694 & 1,680 & 3.9 & 1,880 & 3.7 \\
\hline Tobacco products & 2,103 & 2,302 & 2,534 & $/ 2 /$ & -431 & -17.0 & , & . \\
\hline Textile mill products & 14,801 & 16,139 & 13,531 & 15,087 & 1,270 & 9.4 & 1,053 & 7.0 \\
\hline Apparel and other textile products & 16,792 & 16,652 & 16,506 & 17,053 & 286 & 1.7 & -401 & -2.3 \\
\hline Lumber and wood products & 15,345 & 21,143 & 14,669 & 19,661 & 676 & 4.6 & 1,482 & 7.5 \\
\hline Furniture and fixtures & 10,650 & 13,864 & 10,678 & 13,995 & -28 & -0.3 & -131 & -0.9 \\
\hline Paper and allied products & 24,542 & 28,714 & 23,079 & $/ 2 /$ & 1,463 & 6.3 & . & \\
\hline Printing and publishing & 43,655 & 53,960 & 43,926 & 54,734 & -271 & -0.6 & -774 & -1.4 \\
\hline Chemicals and allied products & 47,911 & 57,677 & 46,835 & 54,291 & 1,076 & 2.3 & 3,386 & 6.2 \\
\hline Petroleum and coal products & 7,568 & 8,221 & 7,246 & 7,787 & 322 & 4.4 & 434 & 5.6 \\
\hline Rubber and miscellaneous plastics products & 24,058 & 31,847 & 25,028 & 32,510 & -970 & -3.9 & -663 & -2.0 \\
\hline Leather and leather products & 2,320 & 2,177 & 1,973 & $/ 2 /$ & 347 & 17.6 & $\ldots$ & $\ldots$ \\
\hline Stone, clay, and glass products & 15,283 & 19,458 & 14,441 & 17,945 & 842 & 5.8 & 1,513 & 8.4 \\
\hline Primary metal industries & 24,612 & 29,819 & 23,483 & 28,373 & 1,129 & 4.8 & 1,446 & 5.1 \\
\hline Fabricated metal products & 39,745 & 51,607 & 40,929 & 53,621 & $-1,184$ & -2.9 & $-2,015$ & -3.8 \\
\hline Industrial machinery and equipment & 69,749 & 94,231 & 64,588 & 83,033 & 5,161 & 8.0 & 11,198 & 13.5 \\
\hline Electronic and other electric equipment & 52,057 & 72,228 & 50,812 & 72,257 & 1,245 & 2.5 & -30 & 0.0 \\
\hline Transportation equipment & 74,475 & 88,768 & 69,706 & 77,709 & 4,769 & 6.8 & 11,059 & 14.2 \\
\hline
\end{tabular}


Table A2. BLS and Census Nonagricultural Payroll Data for Private Industries: Comparison of Levels, 1992 and 1997 [Millions of dollars unless otherwise noted]

\begin{tabular}{|c|c|c|c|c|c|c|c|c|}
\hline \multirow[b]{3}{*}{ Industry description } & \multicolumn{2}{|c|}{ BLS } & \multicolumn{2}{|c|}{ Census /1/ } & \multicolumn{4}{|c|}{ Difference in Levels } \\
\hline & \multirow[b]{2}{*}{$\begin{array}{l}1992 \\
\text { (col 1) }\end{array}$} & \multirow[b]{2}{*}{$\begin{array}{l}1997 \\
\text { (col 2) }\end{array}$} & \multirow[b]{2}{*}{$\begin{array}{l}1992 \\
(\operatorname{col} 3)\end{array}$} & \multirow[b]{2}{*}{$\begin{array}{l}1997 \\
(\mathrm{col} 4)\end{array}$} & \multicolumn{2}{|c|}{1992} & \multicolumn{2}{|c|}{1997} \\
\hline & & & & & $\begin{array}{c}\text { In dollars } \\
(\mathrm{col} 5)= \\
(\operatorname{col} 1)-(\operatorname{col} 3)\end{array}$ & $\begin{array}{c}\text { As percent } \\
\text { of Census level } \\
(\operatorname{col} 6)= \\
(\operatorname{col} 5) /(\operatorname{col} 1)\end{array}$ & $\begin{array}{c}\text { In dollars } \\
(\mathrm{col} 7)= \\
(\mathrm{col} 2)-(\mathrm{col} 4)\end{array}$ & $\begin{array}{c}\text { As percent } \\
\text { of Census level } \\
(\mathrm{col} 8)= \\
(\mathrm{col} 7) /(\mathrm{col} 2)\end{array}$ \\
\hline Instruments and related products & 35,932 & 41,585 & 36,613 & $/ 2 /$ & -681 & -1.9 & $\ldots$ & $\ldots$ \\
\hline Miscellaneous manufacturing industries & 9,210 & 11,438 & 9,189 & 11,329 & 21 & 0.2 & 110 & 1.0 \\
\hline Transportation, communication, utilities $/ 3 /$ & 178,919 & 232,237 & $/ 2 /$ & 205,932 & & $\cdots$ & 26,305 & 12.8 \\
\hline Local and interurban passenger transportation & 5,624 & 7,887 & 5,394 & $/ 2 /$ & 230 & 4.3 & 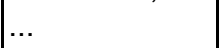 & $\ldots$ \\
\hline Motor freight transportation and warehousing & 35,536 & 49,536 & 41,070 & 57,503 & $-5,534$ & -13.5 & $-7,967$ & -13.9 \\
\hline Water transportation & 5,949 & 6,925 & 5,481 & 6,732 & 468 & 8.5 & 192 & 2.9 \\
\hline Transportation by air $/ 3 /$ & 32,285 & 41,176 & $/ 2 /$ & 11,931 &. & $\ldots$ & & $\ldots$ \\
\hline Pipelines, except natural gas & 975 & 840 & 821 & 790 & 154 & 18.7 & 51 & 6.4 \\
\hline Transportation services & 8,959 & 13,156 & 8,225 & $/ 2 /$ & 734 & 8.9 & & $\ldots$ \\
\hline Communications & 48,908 & 67,823 & 47,742 & 65,261 & 1,166 & 2.4 & 2,562 & 3.9 \\
\hline Electric, gas, and sanitary services & 40,683 & 44,894 & 39,623 & 42,219 & 1,060 & 2.7 & 2,676 & 6.3 \\
\hline Wholesale trade & 199,687 & 263,529 & 188,780 & 251,952 & 10,907 & 5.8 & 11,577 & 4.6 \\
\hline Retail trade & 268,207 & 348,478 & 249,328 & 322,920 & 18,879 & 7.6 & 25,558 & 7.9 \\
\hline Finance, insurance, real estate & 225,110 & 312,156 & 214,504 & 313,245 & 10,606 & 4.9 & $-1,088$ & -0.3 \\
\hline Depository institutions & 59,464 & 73,530 & 57,479 & $/ 2 /$ & 1,985 & 3.5 & & $\ldots$ \\
\hline Nondepository credit institutions & 15,007 & 25,186 & 16,509 & $/ 2 /$ & $-1,502$ & -9.1 & & $\ldots$ \\
\hline Security and commodity brokers and dealers & 39,908 & 67,816 & 34,390 & $/ 2 /$ & 5,518 & 16.0 & & $\ldots$ \\
\hline Insurance carriers & 49,457 & 61,731 & 50,559 & 66,763 & $-1,102$ & -2.2 & $-5,032$ & -7.5 \\
\hline Insurance agents, brokers, and services & 21,327 & 28,610 & 19,123 & 25,907 & 2,204 & 11.5 & 2,703 & 10.4 \\
\hline Real estate & 29,634 & 39,506 & 26,817 & 34,382 & 2,817 & 10.5 & 5,124 & 14.9 \\
\hline Holding and other investment offices & 10,313 & 15,777 & 9,626 & 14,712 & 687 & 7.1 & 1,065 & 7.2 \\
\hline Services & 660,165 & 954,933 & 655,243 & 937,360 & 4,922 & 0.8 & 17,574 & 1.9 \\
\hline Hotels and other lodging places $/ 5 /$ & 22,707 & 30,358 & 20,615 & 28,426 & $\ldots$ & $\ldots$ & 1,932 & 6.8 \\
\hline Personal services $/ 4 / / 5 /$ & 15,071 & 18,965 & 14,950 & 18,432 & & $\ldots$ & & $\ldots$ \\
\hline Business services & 115,010 & 218,755 & 114,446 & 219,148 & 564 & 0.5 & -393 & -0.2 \\
\hline Automotive repair, services, and parking & 17,207 & 25,225 & 16,597 & 24,076 & 610 & 3.7 & 1,149 & 4.8 \\
\hline Miscellaneous repair services & 8,263 & 10,472 & 9,849 & 11,510 & $-1,586$ & -16.1 & $-1,038$ & -9.0 \\
\hline
\end{tabular}


Table A2. BLS and Census Nonagricultural Payroll Data for Private Industries: Comparison of Levels, 1992 and 1997

[Millions of dollars unless otherwise noted]

\begin{tabular}{|c|c|c|c|c|c|c|c|c|}
\hline \multirow[b]{3}{*}{ Industry description } & \multicolumn{2}{|c|}{ BLS } & \multicolumn{2}{|c|}{ Census /1/ } & \multicolumn{4}{|c|}{ Difference in Levels } \\
\hline & \multirow[b]{2}{*}{$\begin{array}{l}1992 \\
(\operatorname{col} 1)\end{array}$} & \multirow[b]{2}{*}{$\begin{array}{l}1997 \\
\text { (col 2) }\end{array}$} & \multirow[b]{2}{*}{$\begin{array}{l}1992 \\
\text { (col 3) }\end{array}$} & \multirow[b]{2}{*}{$\begin{array}{l}1997 \\
(\mathrm{col} 4)\end{array}$} & \multicolumn{2}{|c|}{1992} & \multicolumn{2}{|c|}{1997} \\
\hline & & & & & $\begin{array}{c}\text { In dollars } \\
(\mathrm{col} 5)= \\
(\operatorname{col} 1)-(\operatorname{col} 3)\end{array}$ & \begin{tabular}{|c|} 
As percent \\
of Census level \\
$(\operatorname{col} 6)=$ \\
$(\operatorname{col} 5) /(\operatorname{col} 1)$
\end{tabular} & $\begin{array}{c}\text { In dollars } \\
(\mathrm{col} 7)= \\
(\mathrm{col} 2)-(\mathrm{col} 4)\end{array}$ & $\begin{array}{c}\text { As percent } \\
\text { of Census level } \\
(\mathrm{col} 8)= \\
(\operatorname{col} 7) /(\operatorname{col} 2)\end{array}$ \\
\hline Motion pictures & 9,611 & 17,114 & 10,160 & 14,395 & -549 & -5.4 & 2,718 & 18.9 \\
\hline Amusement and recreation services & 20,816 & 32,158 & 19,612 & 30,840 & 1,204 & 6.1 & 1,318 & 4.3 \\
\hline Health services & 236,388 & 305,990 & 278,598 & 353,787 & $-42,210$ & -15.2 & $-47,797$ & -13.5 \\
\hline Legal services & 40,480 & 48,093 & 39,995 & 48,231 & 485 & 1.2 & -138 & -0.3 \\
\hline Educational services /4/ /7/ & 31,413 & 42,804 & 3,550 & 4,326 & $\ldots$ & $\ldots$ & 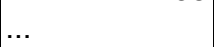 & .. \\
\hline Social services & 27,508 & 40,761 & 25,565 & 34,984 & 1,943 & 7.6 & 5,777 & 16.5 \\
\hline Museums, art galleries, and botanical gardens /6/ & 1,274 & 1,828 & 1,233 & 1,812 & $\ldots$ & ". & 16 & 0.9 \\
\hline Membership organizations /4/ & 15,458 & 20,256 & 10,188 & 683 & 5,270 & 51.7 & & $\ldots$ \\
\hline Engineering and accounting services $/ 5 /$ & 96,960 & 139,415 & 81,339 & 128,710 & & ... & 10,704 & 8.3 \\
\hline Services, not elsewhere classified & 1,999 & 2,741 & 3,121 & & $-1,122$ & -35.9 & & $\ldots$ \\
\hline
\end{tabular}

Notes:

/1/ Equals the published Census payroll estimate for an industry plus published estimate for auxiliaries serving the industry.

12/ Data not disclosed by Census.

/3/ Census data exclude large certificated air carriers

14/ Census data exclude non taxables in 1997.

/5/ Census data exclude non taxables in 1992.

/6/ Census data exclude taxables in 1992.

/7/ Census data exclude private elementary and secondary schools and colleges and universities. 
Table A3. Comparisons in Growth Rates for Census and BLS Payroll Data by Industry, 1992-97

\begin{tabular}{|c|c|c|c|}
\hline Industry Description & $\begin{array}{c}\text { BLS Wages Data } \\
\text { 92-97 Growth Rate } \\
\text { (percent) /1/ }\end{array}$ & $\begin{array}{c}\text { Census Payroll Data } \\
\text { 92-97 Growth Rate } \\
\text { (percent) /1/ }\end{array}$ & $\begin{array}{c}\text { BLS less Census } \\
\text { (percent) }\end{array}$ \\
\hline Total Private /2/ & 6.1 & $\ldots$ & $\ldots$ \\
\hline Mining & 2.5 & 1.5 & 0.9 \\
\hline Metal mining & 4.0 & $\ldots$ & $\ldots$ \\
\hline Coal mining & -2.5 & $\ldots$ & $\ldots$ \\
\hline Oil and gas extraction & 3.2 & 2.6 & 0.6 \\
\hline Nonmetallic minerals, except fuels & 4.8 & 4.3 & 0.5 \\
\hline Construction & 8.0 & 7.7 & 0.2 \\
\hline Manufacturing & 4.4 & 4.0 & 0.4 \\
\hline Food and kindred products & 3.3 & 3.3 & 0.0 \\
\hline Tobacco products & 1.8 & $\ldots$ & $\ldots$ \\
\hline Textile mill products & 1.7 & 2.2 & -0.5 \\
\hline Apparel and other textile products & -0.2 & 0.7 & -0.8 \\
\hline Lumber and wood products & 6.6 & 6.0 & 0.6 \\
\hline Furniture and fixtures & 5.4 & 5.6 & -0.1 \\
\hline Paper and allied products & 3.2 & $\ldots$ & $\ldots$ \\
\hline Printing and publishing & 4.3 & 4.5 & -0.2 \\
\hline Chemicals and allied products & 3.8 & 3.0 & 0.8 \\
\hline Petroleum and coal products & 1.7 & 1.4 & 0.2 \\
\hline Rubber and miscellaneous plastics products & 5.8 & 5.4 & 0.4 \\
\hline Leather and leather products & -1.3 & . & $\ldots$ \\
\hline Stone, clay, and glass products & 4.9 & 4.4 & 0.5 \\
\hline Primary metal industries & 3.9 & 3.9 & 0.1 \\
\hline Fabricated metal products & 5.4 & 5.6 & -0.2 \\
\hline Industrial machinery and equipment & 6.2 & 5.2 & 1.0 \\
\hline Electronic and other electric equipment & 6.8 & 7.3 & -0.5 \\
\hline Transportation equipment & 3.6 & 2.2 & 1.4 \\
\hline Instruments and related products & 3.0 & $\ldots$ & $\ldots$ \\
\hline Miscellaneous manufacturing industries & 4.4 & 4.3 & 0.2 \\
\hline Transportation, communication, utilities /2/ & 5.4 & $\ldots$ & $\ldots$ \\
\hline Local and interurban passenger transportation & 7.0 & $\ldots$ & $\ldots$ \\
\hline Motor freight transportation and warehousing & 6.9 & 7.0 & -0.1 \\
\hline Water transportation & 3.1 & 4.2 & -1.1 \\
\hline Transportation by air /2/ & 5.0 & . & $\ldots$ \\
\hline Pipelines, except natural gas & -2.9 & -0.8 & -2.1 \\
\hline Transportation services & 8.0 & $\ldots$ & $\ldots$ \\
\hline Communications & 6.8 & 6.5 & 0.3 \\
\hline Electric, gas, and sanitary services & 2.0 & 1.3 & 0.7 \\
\hline Wholesale trade & 5.7 & 5.9 & -0.2 \\
\hline Retail trade & 5.4 & 5.3 & 0.1 \\
\hline Finance, insurance, real estate & 6.8 & 7.9 & -1.1 \\
\hline Depository institutions & 4.3 & $\ldots$ & $\ldots$ \\
\hline Nondepository credit institutions & 10.9 & $\ldots$ & $\ldots$ \\
\hline Security and commodity brokers and dealers & 11.2 & $\ldots$ & $\ldots$ \\
\hline Insurance carriers & 4.5 & 5.7 & -1.2 \\
\hline Insurance agents, brokers, and services & 6.1 & 6.3 & -0.2 \\
\hline
\end{tabular}


Table A3. Comparisons in Growth Rates for Census and BLS Payroll Data by Industry, 1992-97

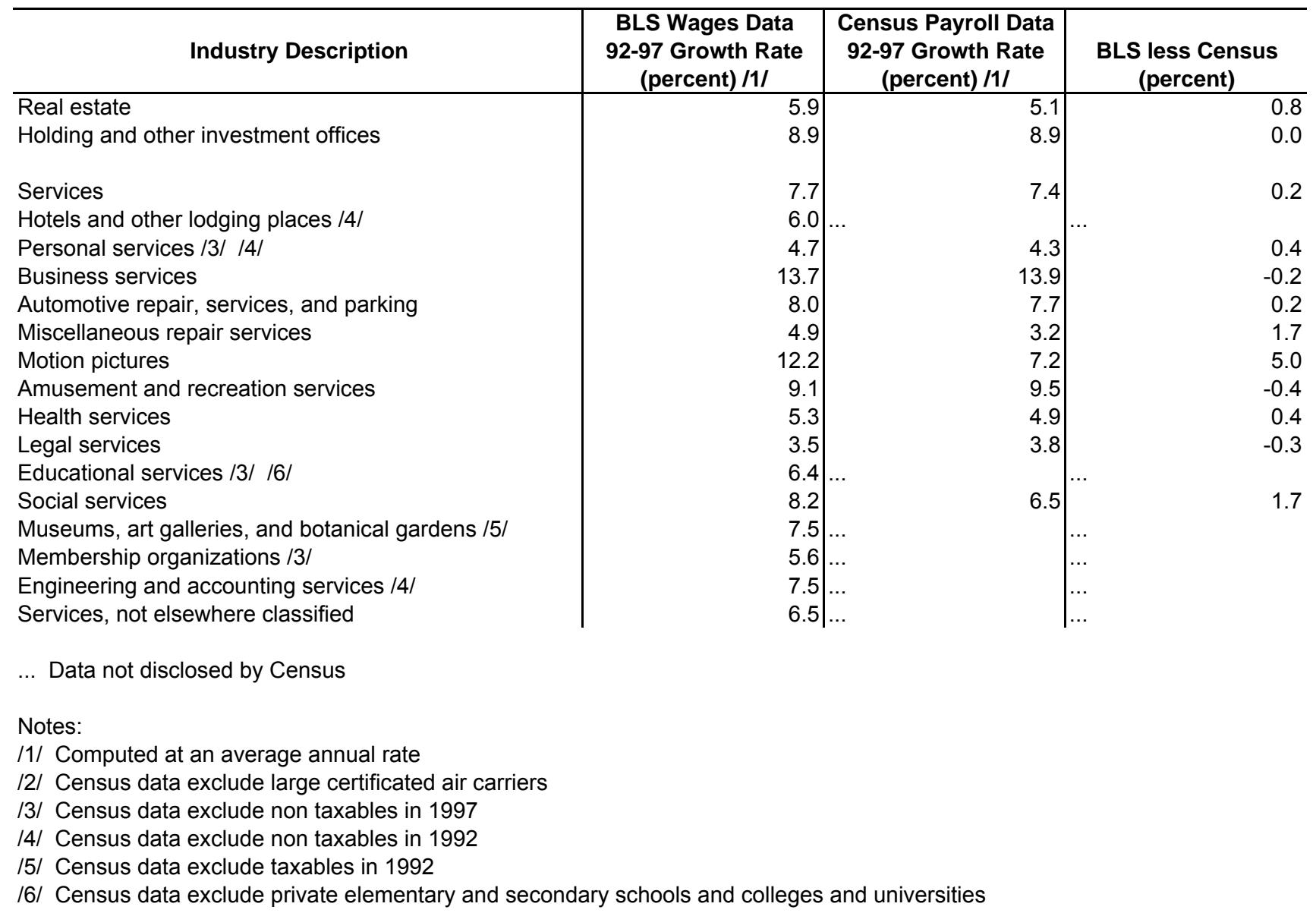




\begin{tabular}{|c|c|}
\hline 1997 NAICS industries & 1997 NAICS codes \\
\hline \multicolumn{2}{|l|}{ All industries } \\
\hline \multicolumn{2}{|l|}{ Private industries } \\
\hline Agriculture, forestry, fishing, and hunting & 11 \\
\hline Farms & 111,112 \\
\hline Forestry, fishing, and related activities & $113,114,115$ \\
\hline Mining & 21 \\
\hline Oil and gas extraction & 211 \\
\hline Mining, except oil and gas & 212 \\
\hline Support activities for mining & 213 \\
\hline Utilities & 22 \\
\hline Construction & 23 \\
\hline Manufacturing & $31,32,33$ \\
\hline Durable goods & $33,321,327$ \\
\hline Wood products & 321 \\
\hline Nonmetallic mineral products & 327 \\
\hline Primary metals & 331 \\
\hline Fabricated metal products & 332 \\
\hline Machinery & 333 \\
\hline Computer and electronic products & 334 \\
\hline Electrical equipment, appliances, and components & 335 \\
\hline Motor vehicle, bodies and trailers, and parts & $3361,3362,3363$ \\
\hline Other transportation equipment & $3364,3365,3366,3369$ \\
\hline Furniture and related products & 337 \\
\hline Miscellaneous manufacturing & 339 \\
\hline Nondurable goods & 31,32 (except 321 and 327 ) \\
\hline Food and beverage and tobacco products & 311,312 \\
\hline Textile mills and textile product mills & 313,314 \\
\hline Apparel and leather and allied products & 315,316 \\
\hline Paper products & 322 \\
\hline Printing and related support activities & 323 \\
\hline Petroleum and coal products & 324 \\
\hline Chemical products & 325 \\
\hline Plastics and rubber products & 326 \\
\hline Wholesale trade & 42 \\
\hline Retail trade & 44,45 \\
\hline Transportation and warehousing & 48,49 \\
\hline Air transportation & 481 \\
\hline Rail transportation & 482 \\
\hline Water transportation & 483 \\
\hline Truck transportation & 484 \\
\hline Transit and ground passenger transportation & 485 \\
\hline Pipeline transportation & 486 \\
\hline Other transportation and support activities & $487,488,492$ \\
\hline Warehousing and storage & 493 \\
\hline Information & 51 \\
\hline Publishing industries (includes software) & 511 \\
\hline Motion picture and sound recording industries & 512 \\
\hline Broadcasting and telecommunications & 513 \\
\hline Information and data processing services & 514 \\
\hline Finance and insurance & 52 \\
\hline Federal Reserve banks, credit intermediation, and related activities & 521,522 \\
\hline Securities, commodity contracts, and investments & 523 \\
\hline Insurance carriers and related activities & 524 \\
\hline Funds, trusts, and other financial vehicles & 525 \\
\hline Real estate and rental and leasing & 53 \\
\hline Real estate & 531 \\
\hline Rental and leasing services and lessors of intangible assets & 532,533 \\
\hline Professional, scientific, and technical services & 54 \\
\hline Legal services & 5411 \\
\hline Computer systems design and related services & 5415 \\
\hline Miscellaneous professional, scientific, and technical services & $5412-5414,5416-5419$ \\
\hline Management of companies and enterprises & 55 \\
\hline Administrative and waste management services & 56 \\
\hline Administrative and support services & 561 \\
\hline Waste management and remediation services & 562 \\
\hline Educational services & 61 \\
\hline Health care and social assistance & 62 \\
\hline Ambulatory health care services & 621 \\
\hline Hospitals and nursing and residential care facilities & 622,623 \\
\hline Social assistance & 624 \\
\hline Arts, entertainment, and recreation & 71 \\
\hline Performing arts, spectator sports, museums, and related activities & 711,712 \\
\hline Amusements, gambling, and recreation industries & 713 \\
\hline Accommodation and food services & 72 \\
\hline Accommodation & 721 \\
\hline Food services and drinking places & 722 \\
\hline Other services, except government & 81 \\
\hline Government & 92 \\
\hline Federal & n.a. \\
\hline General government & n.a. \\
\hline Government enterprises & n.a. \\
\hline State and local & n.a. \\
\hline General government & n.a. \\
\hline Government enterprises & n.a. \\
\hline
\end{tabular}


Table C. NIPA Changes Incorporated into the 1997 Benchmark Input-Output (I-O) Accounts

\begin{tabular}{|l|l|}
\hline \multicolumn{1}{|c|}{ NIPA changes } & \multicolumn{1}{|c|}{ I-O components affected } \\
\hline $\begin{array}{l}\text { Recognize the implicit services provided by property } \\
\text { and casualty insurance companies and provide a more } \\
\text { appropriate treatment of insured losses. }\end{array}$ & $\begin{array}{l}\text { Industry and commodity gross output for insurance } \\
\text { carriers and related activities; intermediate inputs and } \\
\text { gross operating surplus for all industries; final uses. }\end{array}$ \\
\hline $\begin{array}{l}\text { Allocate a portion of the implicit services of } \\
\text { commercial banks to borrowers. }\end{array}$ & $\begin{array}{l}\text { Industry and commodity gross output for Federal } \\
\text { Reserve banks, credit intermediation and related } \\
\text { activities; intermediate inputs and gross operating } \\
\text { surplus for all industries; final uses. }\end{array}$ \\
\hline $\begin{array}{l}\text { Redefine change in private farm inventories to include } \\
\text { farm materials and supplies. }\end{array}$ & $\begin{array}{l}\text { Intermediate inputs and gross operating surplus for } \\
\text { the farms industry; change in private inventories. }\end{array}$ \\
\hline $\begin{array}{l}\text { Reclassify Indian tribal government activities from the } \\
\text { private sector to the state and local government sector. }\end{array}$ & $\begin{array}{l}\text { Gross output, intermediate inputs, and value added } \\
\text { for the amusements, gambling, and recreation; } \\
\text { accommodation; and state and local government } \\
\text { enterprises industries; state and local general } \\
\text { government. }\end{array}$ \\
\hline $\begin{array}{l}\text { Reclassify military grants-in-kind as exports. } \\
\text { Recognize explicitly the services produced by general } \\
\text { government and treat government purchases of goods } \\
\text { and services as intermediate inputs. }\end{array}$ & $\begin{array}{l}\text { Fross output and intermediate inputs for the state and } \\
\text { local general government and Federal general } \\
\text { government industries. }\end{array}$ \\
\hline $\begin{array}{l}\text { Reclassify business nontax liability as current transfer } \\
\text { government. }\end{array}$ & $\begin{array}{l}\text { Taxes on production and imports, less subsidies and } \\
\text { gross operating surplus for all industries; gross } \\
\text { output for the rental and leasing services and lessors } \\
\text { of intangible assets industry; purchases of the rental } \\
\text { and leasing services and lessors of intangible assets } \\
\text { commodity by selected industries. }\end{array}$ \\
\hline
\end{tabular}

NIPA National income and product accounts

\footnotetext{
1 For details, see Brent R. Moulton and Eugene P. Seskin, "Preview of the 2003 Comprehensive Revision of the National Income and Product Accounts: Changes in Definitions and Classifications," Survey of Current Business 83 (June 2003 ): 20.
} 
Table D. 1997 Industry Value Added Estimates

\begin{tabular}{|c|c|c|c|}
\hline Industry & $\begin{array}{c}\text { Revised } \\
\text { benchmark I- } \\
\text { O accounts }\end{array}$ & $\begin{array}{l}\text { GDP-by } \\
\text { industry } \\
\text { accounts }\end{array}$ & Combined \\
\hline Farms... & 88,142 & 88,142 & 88,142 \\
\hline Forestry, fishing, and related activities. & 21,110 & 23,771 & 22,595 \\
\hline Oil and gas extraction... & 48,084 & 59,236 & 52,902 \\
\hline Mining, except oil and gas.. & 25,869 & 27,854 & 26,414 \\
\hline Support activities for mining. & 11,941 & 18,439 & 13,333 \\
\hline Utilities.................. & 162,264 & 180,852 & 180,289 \\
\hline Construction.. & 310,029 & 346,223 & 337,558 \\
\hline Wood products. & 26,207 & 30,666 & 28,008 \\
\hline Nonmetallic mineral products.. & 40,720 & 37,829 & 40,708 \\
\hline Primary metals.................... & 43,799 & 51,214 & 48,337 \\
\hline Fabricated metal products.. & 114,396 & 102,625 & 108,119 \\
\hline Machinery.................... & 104,664 & 88,649 & 98,164 \\
\hline Computer and electronic products.... & 178,019 & 144,110 & 154,403 \\
\hline Electrical equipment, appliances, and components.. & 41,230 & 79,140 & 45,596 \\
\hline Motor vehicle, bodies and trailers, and parts.. & 93,396 & 117,083 & 103,195 \\
\hline Other transportation equipment.. & 55,538 & 52,444 & 54,418 \\
\hline Furniture and related products.. & 28,181 & 25,568 & 27,060 \\
\hline Miscellaneous manufacturing.. & 47,861 & 47,793 & 47,729 \\
\hline Food and beverage and tobacco products. & 158,928 & 130,224 & 135,357 \\
\hline Textile mills and textile product mills.......... & 26,012 & 27,829 & 26,996 \\
\hline Apparel and leather and allied products..... & 28,918 & 26,249 & 27,186 \\
\hline Paper products.............................. & 51,046 & 51,354 & 51,484 \\
\hline Printing and related support activities....... & 42,725 & 47,362 & 44,667 \\
\hline Petroleum and coal products............. & 22,595 & 67,926 & 27,116 \\
\hline Chemical products............. & 149,879 & 150,776 & 150,846 \\
\hline Plastics and rubber products. & 62,402 & 49,828 & 60,704 \\
\hline Wholesale trade............... & 487,913 & 531,865 & 521,250 \\
\hline Retail trade............ & 517,499 & 588,270 & 574,192 \\
\hline Air transportation.. & 45,285 & 55,017 & 49,457 \\
\hline Rail transportation.. & 23,133 & 22,590 & 23,030 \\
\hline Water transportation... & 7,162 & 6,273 & 6,510 \\
\hline Truck transportation... & 87,016 & 76,343 & 80,524 \\
\hline Transit and ground passenger transportation... & 17,090 & 12,164 & 12,978 \\
\hline Pipeline transportation................................. & 9,227 & 8,095 & 8,774 \\
\hline Other transportation and support activities..... & 50,523 & 59,586 & 55,032 \\
\hline Warehousing and storage $\ldots \ldots \ldots \ldots \ldots \ldots \ldots \ldots$ & 19,014 & 20,003 & 19,549 \\
\hline Publishing industries (includes software).......... & 114,475 & 65,572 & 87,457 \\
\hline Motion picture and sound recording industries.............. & 25,272 & 22,899 & 24,298 \\
\hline Broadcasting and telecommunications.... & 196,395 & 212,151 & 208,862 \\
\hline Information and data processing services... & 30,418 & 18,550 & 27,189 \\
\hline Federal Reserve banks, credit intermediation, and related activities.. & 274,457 & 251,974 & 259,541 \\
\hline Securities, commodity contracts, and investments... & 107,598 & 131,109 & 119,470 \\
\hline Insurance carriers and related activities............... & 175,610 & 217,464 & 206,566 \\
\hline Funds, trusts, and other financial vehicles.. & 9,957 & 9,882 & 9,965 \\
\hline 1 & 944,801 & 886,560 & 908,544 \\
\hline
\end{tabular}


Table D. 1997 Industry Value Added Estimates

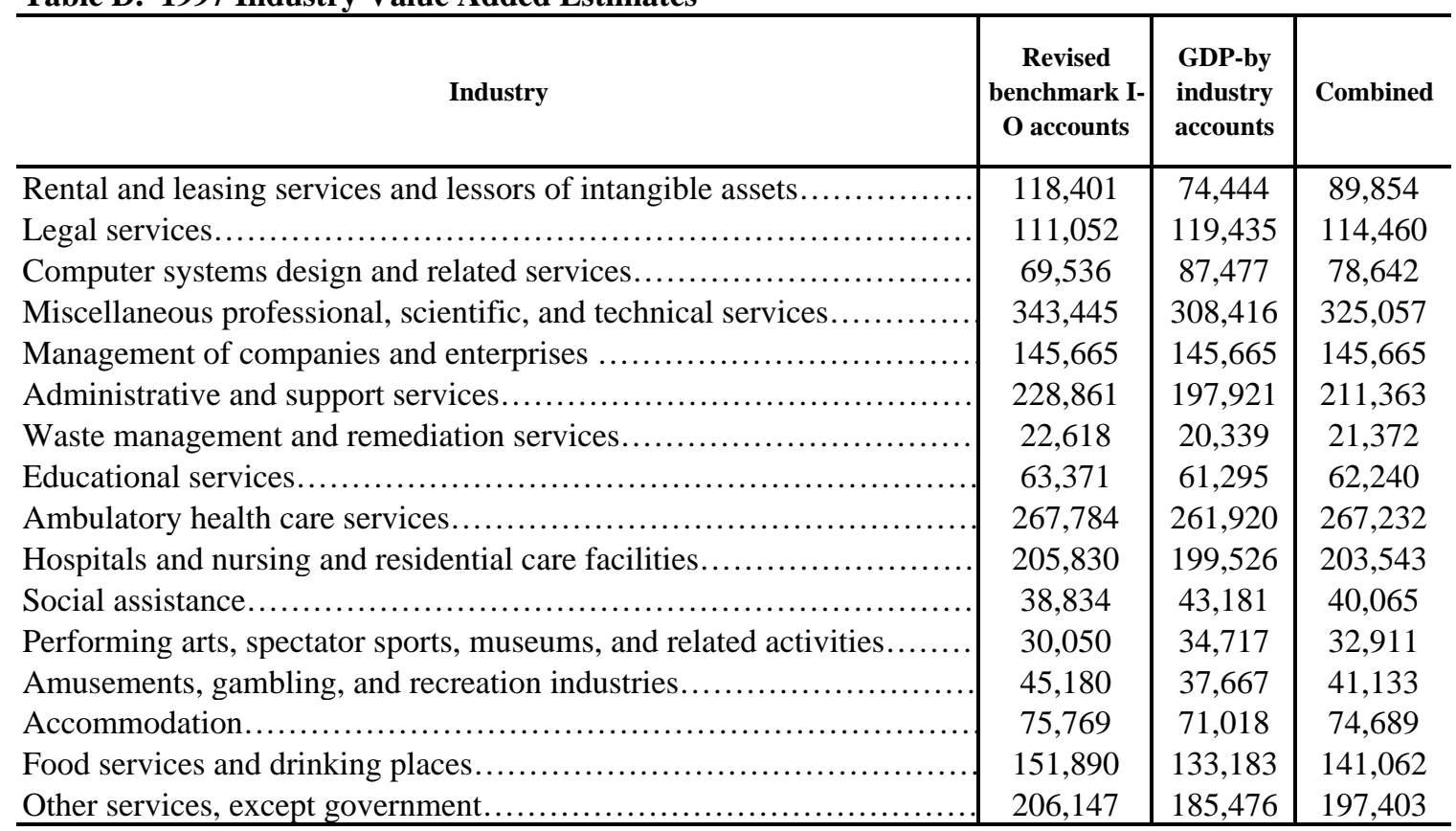


Table F. Principal Sources of Data for Industry and Commodity Output and Prices

\begin{tabular}{|c|c|c|}
\hline Industry and commodity & Source data for extrapolator & Source data for price index \\
\hline \multicolumn{3}{|l|}{$\begin{array}{l}\text { Agriculture, forestry, fishing } \\
\text { and hunting }\end{array}$} \\
\hline Farms................ & $\begin{array}{l}\text { USDA cash receipts from } \\
\text { marketing and inventory } \\
\text { change. }\end{array}$ & $\begin{array}{l}\text { USDA prices received by farmers; } \\
\text { PPI. }\end{array}$ \\
\hline $\begin{array}{l}\text { Forestry, fishing, and } \\
\text { related activities....... }\end{array}$ & $\begin{array}{l}\text { For forestry, Census Bureau } \\
\text { shipments; for fishing, NOAA } \\
\text { value of fish landings; for } \\
\text { related activities, NIPA } \\
\text { estimates. }\end{array}$ & PPI; NOAA; NIPA deflator. \\
\hline \multicolumn{3}{|l|}{ Mining } \\
\hline Oil and gas extraction... & $\begin{array}{l}\text { DOE quantity produced and } \\
\text { prices. }\end{array}$ & $\begin{array}{l}\text { For crude petroleum and natural } \\
\text { gas, IPD from DOE; for natural } \\
\text { gas liquids, PPI. }\end{array}$ \\
\hline $\begin{array}{l}\text { Mining, except oil and } \\
\text { gas................... }\end{array}$ & $\begin{array}{l}\text { DOE quantity produced and } \\
\text { average price for uranium and } \\
\text { coal; USGS quantity and price } \\
\text { data for all others. }\end{array}$ & IPD from DOE and USGS. \\
\hline $\begin{array}{l}\text { Support activities for } \\
\text { mining.................. }\end{array}$ & $\begin{array}{l}\text { DOE, USGS, and trade sources } \\
\text { for quantity produced and } \\
\text { prices. }\end{array}$ & $\begin{array}{l}\text { IPD from DOE, USGS and trade } \\
\text { sources; for exploration, PPI. }\end{array}$ \\
\hline \multicolumn{3}{|l|}{ Utilities } \\
\hline Electric utilities.......... & EIA. & PPI. \\
\hline Natural gas.............. & EIA quantity and price data. & PPI. \\
\hline $\begin{array}{l}\text { Water, sewage, and } \\
\text { other systems.......... }\end{array}$ & PCE. & CPI. \\
\hline
\end{tabular}




\begin{tabular}{|c|c|c|}
\hline Industry and commodity & Source data for extrapolator & Source data for price index \\
\hline \multicolumn{3}{|l|}{ Construction } \\
\hline $\begin{array}{l}\text { For the Department of } \\
\text { Defense (DOD) .......... }\end{array}$ & DOD expenditures data. & $\begin{array}{l}\text { DOD prices for military } \\
\text { construction; cost indexes from } \\
\text { trade sources and government } \\
\text { agencies for other construction. }\end{array}$ \\
\hline $\begin{array}{l}\text { For state and local } \\
\text { highways.............. }\end{array}$ & $\begin{array}{l}\text { Census Bureau data from the } \\
\text { ASGF. }\end{array}$ & $\begin{array}{l}\text { Cost indexes from government } \\
\text { agencies. }\end{array}$ \\
\hline $\begin{array}{l}\text { For private electric and } \\
\text { gas utilities............. }\end{array}$ & $\begin{array}{l}\text { Federal regulatory agencies and } \\
\text { trade sources expenditures } \\
\text { data. }\end{array}$ & $\begin{array}{l}\text { Cost indexes from trade sources } \\
\text { and government agencies. }\end{array}$ \\
\hline $\begin{array}{l}\text { For farms, excluding } \\
\text { residential............... }\end{array}$ & USDA expenditures data. & $\begin{array}{l}\text { Trade sources cost index; Census } \\
\text { Bureau price deflator for new } \\
\text { single-family houses under } \\
\text { construction. }\end{array}$ \\
\hline $\begin{array}{l}\text { For other } \\
\text { nonresidential.. }\end{array}$ & $\begin{array}{l}\text { Census Bureau data on value of } \\
\text { construction put in place. }\end{array}$ & $\begin{array}{l}\text { Trade sources and government } \\
\text { agency cost indexes; Census } \\
\text { Bureau price index for new } \\
\text { single-family houses under } \\
\text { construction; BEA quality- } \\
\text { adjusted price indexes for } \\
\text { factories, office buildings, } \\
\text { warehouses, and schools. }\end{array}$ \\
\hline $\begin{array}{l}\text { For other } \\
\text { residential........... }\end{array}$ & $\begin{array}{l}\text { Census Bureau data on value of } \\
\text { construction put in place. }\end{array}$ & $\begin{array}{l}\text { Census Bureau price index for } \\
\text { new single-family houses under } \\
\text { construction; BEA price index } \\
\text { for multifamily construction. }\end{array}$ \\
\hline
\end{tabular}




\begin{tabular}{|c|c|c|}
\hline Industry and commodity & Source data for extrapolator & Source data for price index \\
\hline Manufacturing & $\begin{array}{l}\text { Census Bureau data on } \\
\text { shipments and inventory } \\
\text { change. }\end{array}$ & $\begin{array}{l}\text { PPI; quality adjusted price indexes } \\
\text { for computers, } \\
\text { photocopying equipment, digital } \\
\text { telephone switching equipment, } \\
\text { and LAN equipment; BEA price } \\
\text { indexes based on DOD prices } \\
\text { paid for military equipment. }\end{array}$ \\
\hline Wholesale trade & Census Bureau ATS data. & $\begin{array}{l}\text { Sales price by kind-of-business } \\
\text { computed from PPI. }\end{array}$ \\
\hline Retail trade & Census Bureau ARTS data. & $\begin{array}{l}\text { Sales price by kind-of-business } \\
\text { computed from CPI. }\end{array}$ \\
\hline \multicolumn{3}{|l|}{$\begin{array}{l}\text { Transportation and } \\
\text { warehousing }\end{array}$} \\
\hline Air transportation.......... & $\begin{array}{l}\text { BTS Air Carrier Financial } \\
\text { Statistics. }\end{array}$ & $\begin{array}{l}\text { IPD for total passenger-related } \\
\text { revenues and passenger miles } \\
\text { from DOT; IPD for total freight-, } \\
\text { mail-, and express-related } \\
\text { revenues and ton miles from } \\
\text { DOT; wages and salaries per } \\
\text { employee from BLS. }\end{array}$ \\
\hline Rail transportation...... & Amtrak and trade sources. & PPI. \\
\hline Water transportation... & $\begin{array}{l}\text { Army Corps of Engineers; trade } \\
\text { sources. }\end{array}$ & $\begin{array}{l}\text { PPI for freight; for passengers, } \\
\text { CPI. }\end{array}$ \\
\hline Truck transportation... & Census Bureau SAS. & PPI. \\
\hline $\begin{array}{l}\text { Transit and ground } \\
\text { passenger } \\
\text { transportation........ }\end{array}$ & PCE; BTS. & $\begin{array}{l}\text { For taxicabs, intercity buses, and } \\
\text { other local transit, PCE price } \\
\text { index; for school buses, BLS } \\
\text { data on wages and salaries per } \\
\text { employee. }\end{array}$ \\
\hline
\end{tabular}




\begin{tabular}{|c|c|c|}
\hline Industry and commodity & Source data for extrapolator & Source data for price index \\
\hline Pipeline transportation... & Trade sources. & PPI. \\
\hline $\begin{array}{l}\text { Other transportation } \\
\text { and support activities.. }\end{array}$ & PCE. & $\begin{array}{l}\text { For sightseeing, PCE price index; } \\
\text { for other transportation and } \\
\text { support activities, PCE price } \\
\text { indexes and PPI. }\end{array}$ \\
\hline $\begin{array}{l}\text { Warehousing and } \\
\text { Storage..................... }\end{array}$ & Census Bureau SAS. & PPI. \\
\hline \multicolumn{3}{|l|}{ Information } \\
\hline $\begin{array}{l}\text { Publishing industries } \\
\text { (includes software)... }\end{array}$ & Census Bureau SAS. & $\begin{array}{l}\text { BEA price indexes for } \\
\text { prepackaged and custom } \\
\text { software for software } \\
\text { publishers; for all other } \\
\text { publishing industries, } \mathrm{PPI} \text {. }\end{array}$ \\
\hline $\begin{array}{l}\text { Motion picture and } \\
\text { sound recording } \\
\text { industries......... }\end{array}$ & Census Bureau SAS. & PCE price indexes. \\
\hline $\begin{array}{l}\text { Broadcasting and } \\
\text { telecommunications... }\end{array}$ & Census Bureau SAS. & $\begin{array}{l}\text { For cable networks, programming, } \\
\text { and telecommunications, PPI; } \\
\text { for radio and television } \\
\text { broadcasting, network receipts, } \\
\text { and all other } \\
\text { telecommunications, composite } \\
\text { price index of PPIs. }\end{array}$ \\
\hline $\begin{array}{l}\text { Information and } \\
\text { data processing } \\
\text { services............ }\end{array}$ & Census Bureau SAS. & $\begin{array}{l}\text { For information services, PCE } \\
\text { price indexes; for data } \\
\text { processing services, PPI. }\end{array}$ \\
\hline \multicolumn{3}{|l|}{ Finance and insurance } \\
\hline $\begin{array}{l}\text { Federal Reserve } \\
\text { banks, credit }\end{array}$ & $\begin{array}{l}\text { FDIC; FRB; NIPA imputed service } \\
\text { charges; NCUA; and other }\end{array}$ & $\begin{array}{l}\text { PCE price indexes; other } \\
\text { government data. }\end{array}$ \\
\hline
\end{tabular}




\begin{tabular}{|c|c|c|}
\hline Industry and commodity & Source data for extrapolator & Source data for price index \\
\hline $\begin{array}{l}\text { intermediation, and } \\
\text { related activities....... }\end{array}$ & private agencies. & \\
\hline $\begin{array}{l}\text { Securities, } \\
\text { commodity contracts, } \\
\text { investments..... }\end{array}$ & SEC FOCUS Report. & PCE price indexes. \\
\hline $\begin{array}{l}\text { Insurance carriers and } \\
\text { related activities........ }\end{array}$ & $\begin{array}{l}\text { Trade sources for insurance } \\
\text { carriers; BEA estimates for } \\
\text { property and casualty } \\
\text { insurance; for all other } \\
\text { insurance, PCE; for insurance } \\
\text { agents, brokers, and services, } \\
\text { IRS tabulations of business tax } \\
\text { returns. }\end{array}$ & $\begin{array}{l}\text { For health and life insurance, PCE } \\
\text { price indexes; for property and } \\
\text { casualty insurance, PPI; for } \\
\text { agents, brokers, and services, } \\
\text { composite price index based on } \\
\text { trade sources data and PCE } \\
\text { price indexes. }\end{array}$ \\
\hline $\begin{array}{l}\text { Funds, trusts, and } \\
\text { other financial } \\
\text { vehicles............. }\end{array}$ & $\begin{array}{l}\text { NIPA imputed service charges for } \\
\text { other financial institutions; } \\
\text { EBSA data on pension funds. }\end{array}$ & $\begin{array}{l}\text { IPD from NIPA imputed service } \\
\text { charges; composite price } \\
\text { index based on PCE price } \\
\text { indexes; PPI data; BLS data on } \\
\text { wages and salaries per full- } \\
\text { time employee. }\end{array}$ \\
\hline \multicolumn{3}{|l|}{$\begin{array}{l}\text { Real estate and rental and } \\
\text { leasing }\end{array}$} \\
\hline Real estate......... & $\begin{array}{l}\text { For residential dwellings and real } \\
\text { estate agents and managers, } \\
\text { NIPA housing data; for } \\
\text { nonresidential dwellings, IRS } \\
\text { tabulations of business tax } \\
\text { returns; NIPA rental value of } \\
\text { buildings owned by nonprofits. }\end{array}$ & $\begin{array}{l}\text { For nonfarm residential dwellings, } \\
\text { NIPA price index; for } \\
\text { nonresidential dwellings, PPI; } \\
\text { for real estate managers and } \\
\text { agents, PPI and trade sources; } \\
\text { IPD for nonprofit and farm } \\
\text { residential dwellings. }\end{array}$ \\
\hline $\begin{array}{l}\text { Rental and leasing } \\
\text { services and lessors } \\
\text { of intangible assets..... }\end{array}$ & $\begin{array}{l}\text { For rental and leasing services, } \\
\text { Census Bureau SAS; for } \\
\text { royalties, IRS tabulations of } \\
\text { business tax returns. }\end{array}$ & $\begin{array}{l}\text { For automotive equipment rental, } \\
\text { PPI; for other rental services, } \\
\text { PCE price indexes; for royalties, } \\
\text { PCE price index and IPD from } \\
\text { DOE and PPI. }\end{array}$ \\
\hline
\end{tabular}




\begin{tabular}{|c|c|c|}
\hline Industry and commodity & Source data for extrapolator & Source data for price index \\
\hline $\begin{array}{l}\text { Professional, scientific, and } \\
\text { technical services }\end{array}$ & & \\
\hline Legal services ............ & Census Bureau SAS. & PPI. \\
\hline $\begin{array}{l}\text { Computer systems } \\
\text { design and related } \\
\text { services............... }\end{array}$ & Census Bureau SAS. & $\begin{array}{l}\text { BEA price indexes for } \\
\text { prepackaged and custom } \\
\text { software. }\end{array}$ \\
\hline $\begin{array}{l}\text { Miscellaneous } \\
\text { professional, scientific } \\
\text { and technical services.. }\end{array}$ & Census Bureau SAS. & $\begin{array}{l}\text { PPI; BLS wages and salaries per } \\
\text { full-time employee. }\end{array}$ \\
\hline $\begin{array}{l}\text { Management of companies } \\
\text { and enterprises }\end{array}$ & BLS wages and salaries. & $\begin{array}{l}\text { BLS wages and salaries per full- } \\
\text { time employee. }\end{array}$ \\
\hline $\begin{array}{l}\text { Administrative and waste } \\
\text { management services }\end{array}$ & & \\
\hline $\begin{array}{l}\text { Administrative and } \\
\text { support services .......... } \\
\text { Waste management } \\
\text { and remediation } \\
\text { services................ }\end{array}$ & $\begin{array}{l}\text { Census Bureau SAS. } \\
\text { Census Bureau SAS. }\end{array}$ & $\begin{array}{l}\text { BLS wages and salaries per full- } \\
\text { time employee; PCE price } \\
\text { indexes; PPI. } \\
\text { CPI. }\end{array}$ \\
\hline Educational services & PCE. & $\begin{array}{l}\text { PCE price index based on trade } \\
\text { sources. }\end{array}$ \\
\hline $\begin{array}{l}\text { Health care and social } \\
\text { assistance } \\
\begin{array}{l}\text { Ambulatory health care } \\
\text { services................... }\end{array}\end{array}$ & Census Bureau SAS. & PPI; PCE price indexes. \\
\hline
\end{tabular}




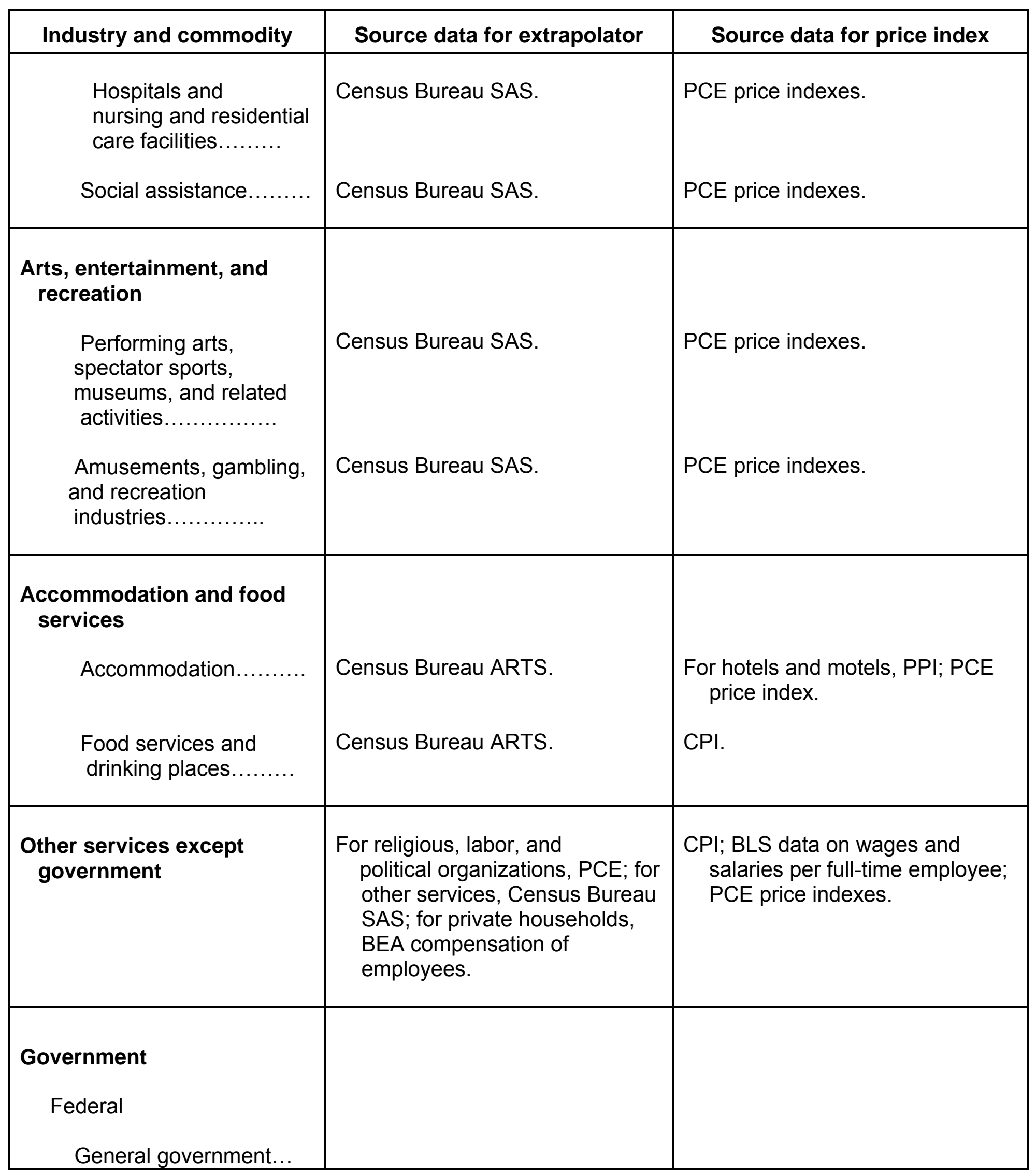




\begin{tabular}{|c|l|l|}
\hline Industry and commodity & \multicolumn{1}{|c|}{ Source data for extrapolator } & \multicolumn{1}{|c|}{ Source data for price index } \\
\hline $\begin{array}{c}\text { Government } \\
\text { enterprises.............. }\end{array}$ & $\begin{array}{l}\text { USPS receipts; for electric } \\
\text { utilities, DOE; other } \\
\text { government data. }\end{array}$ & $\begin{array}{c}\text { For USPS and electric utilities, } \\
\text { PPI; for all others, PCE price } \\
\text { index and NIPA price indexes. }\end{array}$ \\
State and local & General government .... & NIPA price indexes. \\
Government enterprises.. & $\begin{array}{c}\text { For electric utilities, DOE data; for } \\
\text { other enterprises, BEA data on } \\
\text { revenue by type. }\end{array}$ & PPI. \\
\hline
\end{tabular}

ARTS Annual Retail Trade Survey, Census Bureau

ASGF Annual Survey of Government Finances, Census Bureau

ATS Annual Trade Survey, Census Bureau

BEA Bureau of Economic Analysis

BLS Bureau of Labor Statistics

BTS Bureau of Transportation Statistics

CPI Consumer Price Index, BLS

DOC Department of Commerce

DOD Department of Defense

DOE Department of Energy

DOT Department of Transportation

EBSA Employee Benefits Security Administration

EIA Energy Information Administration

FDIC Federal Deposit Insurance Corporation

FOCUS Financial and Operational Combined Uniform Single Report, SEC

FRB Federal Reserve Board of Governors

IPD Implicit price deflator

IRS Internal Revenue Service

NCUA National Credit Union Association

NIPA National income and product accounts, BEA

NOAA National Oceanic and Atmospheric Administration

PCE Personal consumption expenditures, BEA

PPI Producer Price Index, BLS

SAS Service Annual Survey

SEC Securities and Exchange Commission

USDA U.S. Department of Agriculture

USGS U.S. Geological Survey, Office of Minerals

USPS U. S. Postal Service 


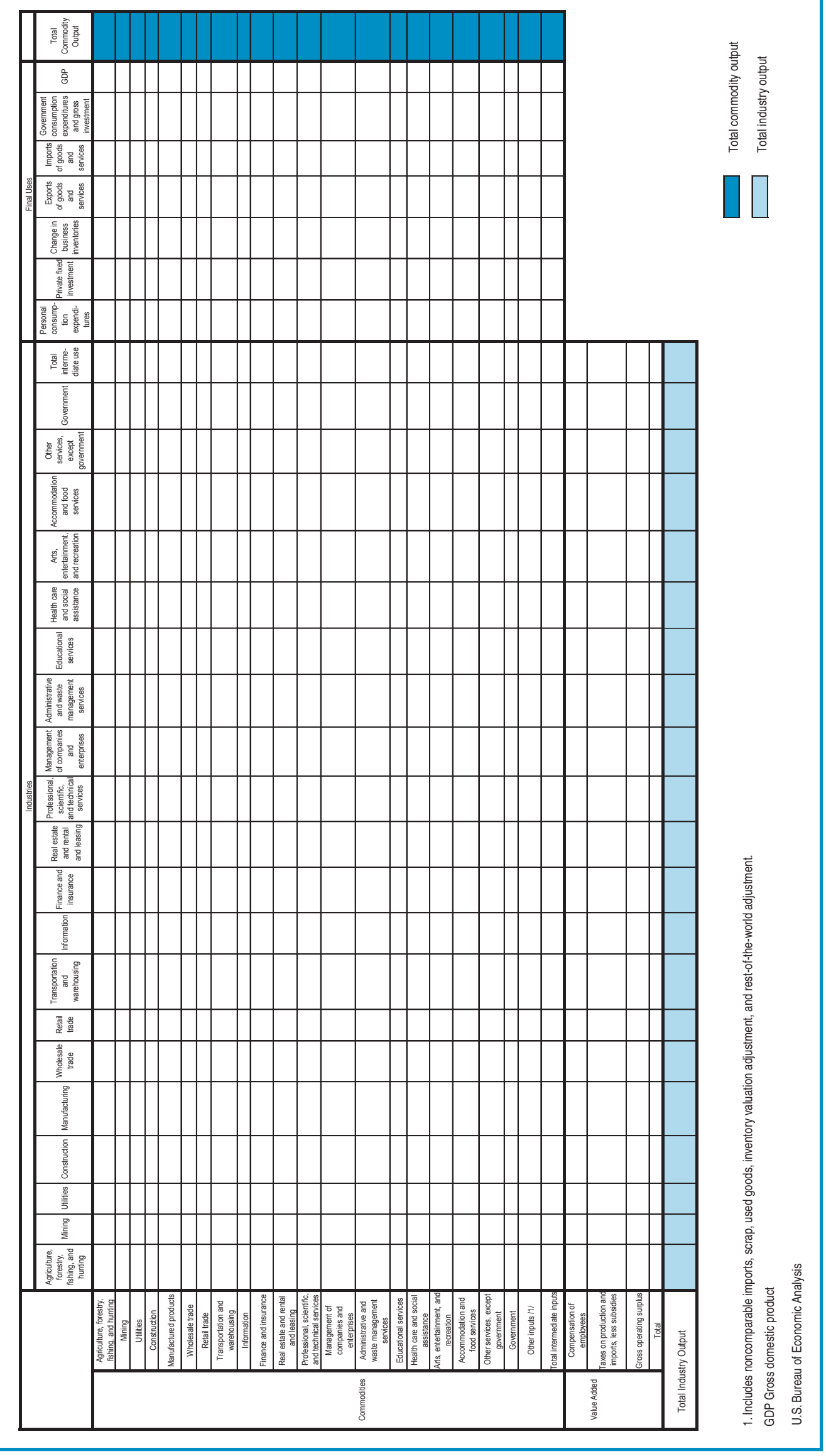




\section{Chart 2. Components of GDI-Based Value Added by Industry}

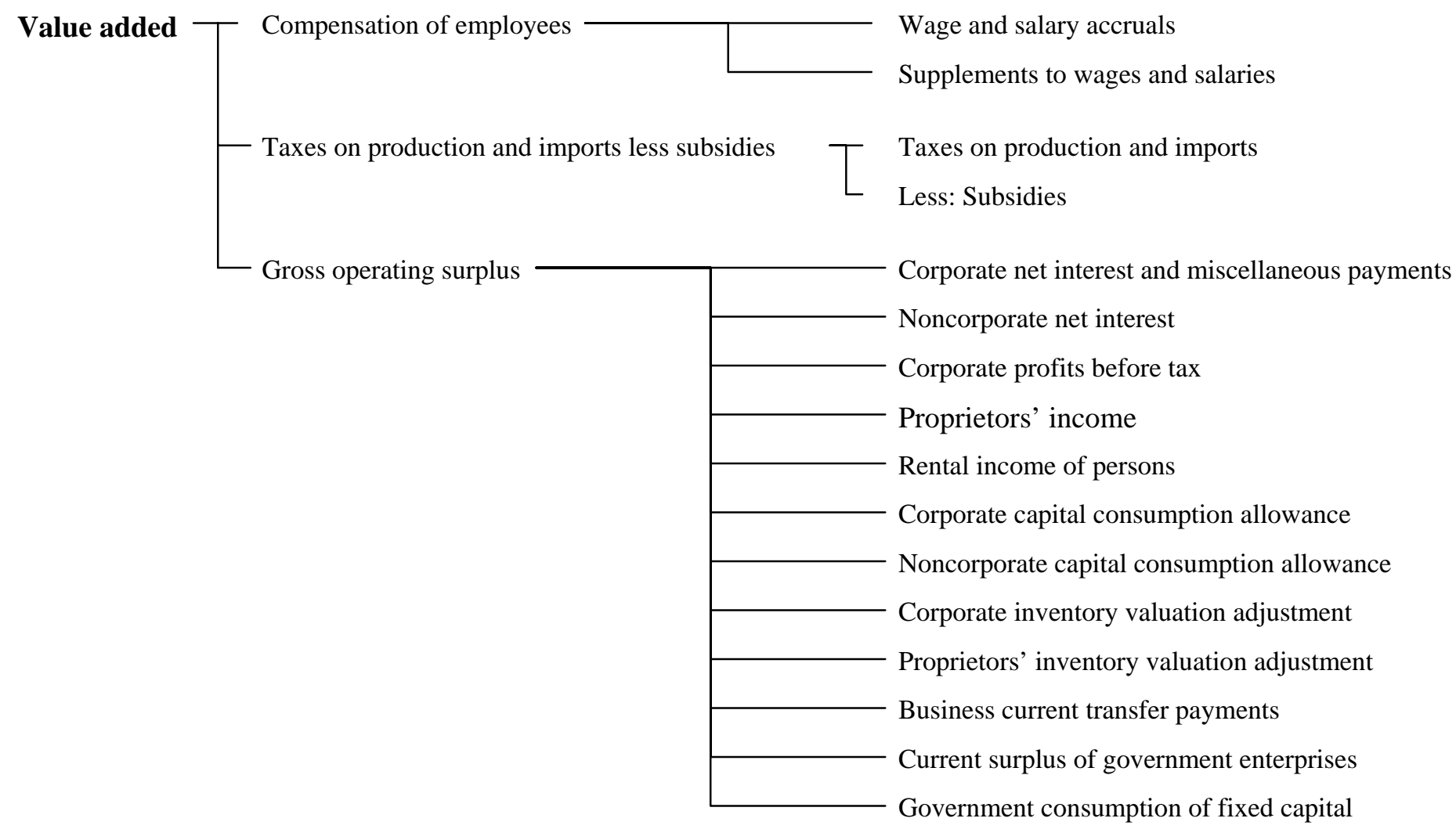

U.S. Bureau of Economic Analysis 


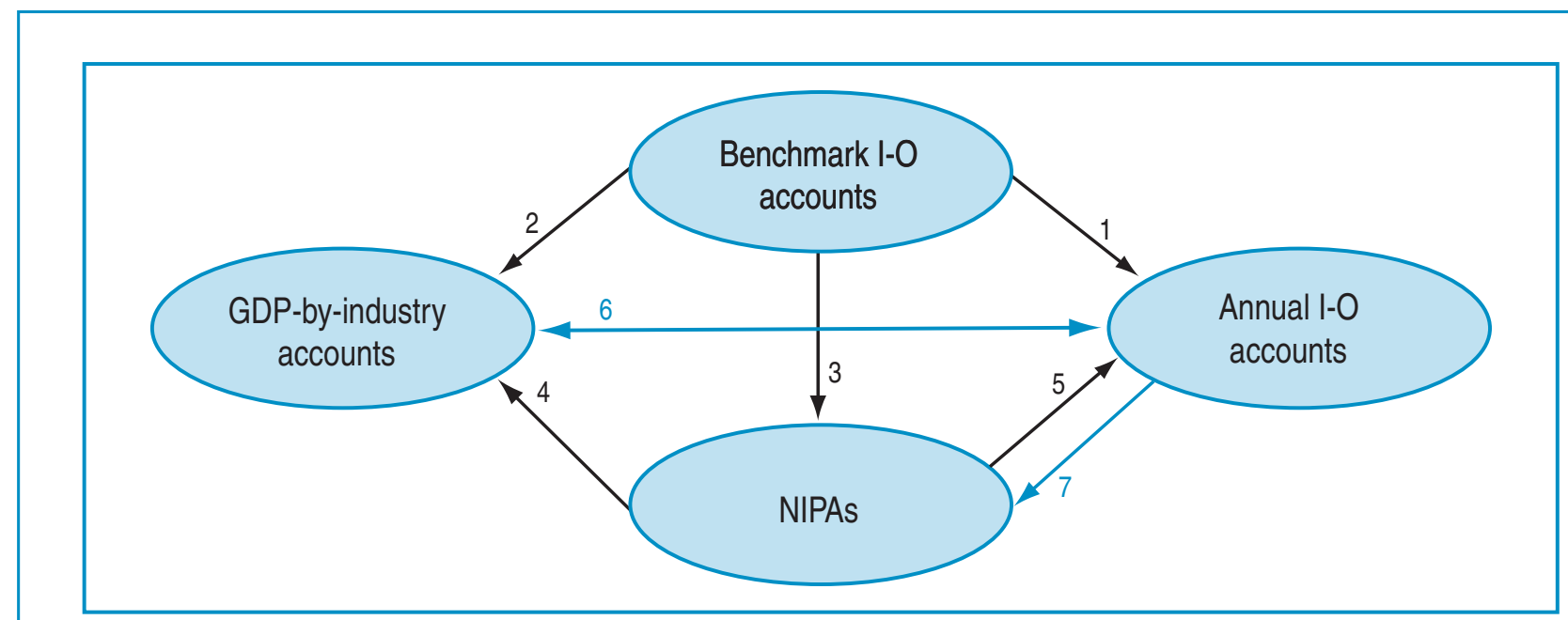

GDP Gross domestic product

I-O Input-output

NIPAs National Income and product accounts

U.S. Bureau of Economic Analysis 


\title{
Chart 4. Merging Information for Setting Value-Added Levels
}

\author{
Benchmark Value Added
}

\begin{tabular}{|c|c|c|}
\cline { 2 - 3 } & $\begin{array}{c}\text { Good Benchmark data/ } \\
\text { good GDP-by-industry data } \\
\begin{array}{c}\text { GDP-by- } \\
\text { Industry } \\
\text { Value } \\
\text { Added }\end{array}\end{array}$ & $\begin{array}{c}\text { Good Benchmark data/ } \\
\text { poor GDP-by-industry data }\end{array}$ \\
$\begin{array}{c}\text { e.g., Health care } \\
\text { Pood GDP-by-industry data } \\
\text { e.g., Transportation/ } \\
\text { Warehousing }\end{array}$ & $\begin{array}{c}\text { Poor Benchmark data/ } \\
\text { poor GDP-by-industry data }\end{array}$ \\
\hline
\end{tabular}

U.S. Bureau of Economic Analysis 

for Educational Services

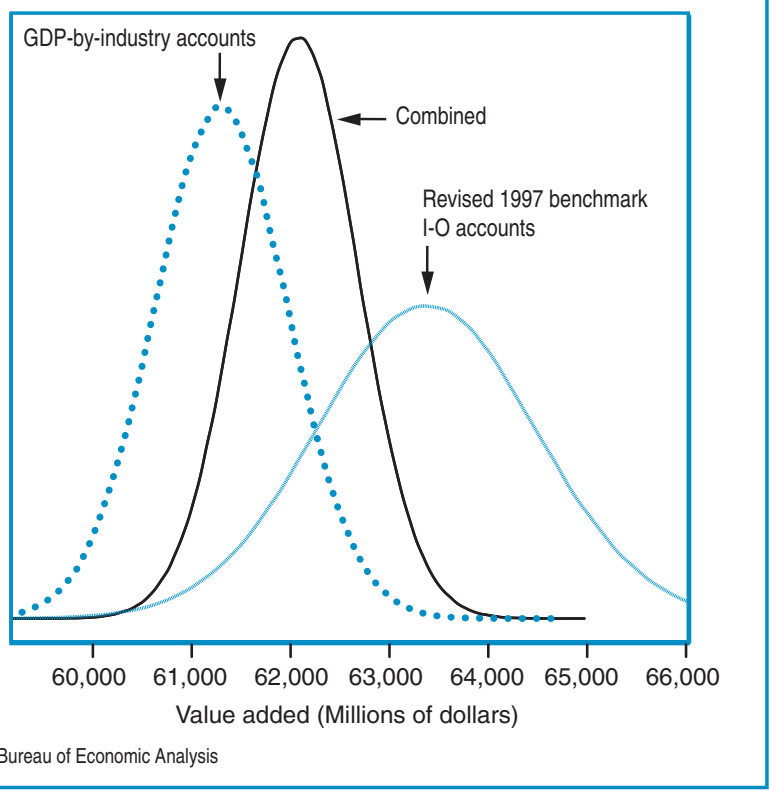

U.S. Bureau of Economic Analysis 